\title{
Determinants of Industry and Region Based Open Innovation in Turkey
}

\author{
Ümit K. Seyfettinoğlu1 $\odot$, Şebnem Arık ${ }^{\oplus}$, Selim Çağatay3 ${ }^{\oplus}$
}

\begin{abstract}
The concept of open innovation has emerged from the thought that firms and institutions do not reveal innovation solely through internal processes as in closed innovations. The process of introducing innovation is accelerated by enabling the knowledge inflow to and outflow from the company; and the competitive power is achieved not by producing the best and the greatest number of ideas/projects but by using the inner and outer ideas in the most efficient way. The literature has defined the stages of open innovation throughout the production process as idea generation, idea development, experience, engineering, manufacturing and commercialization. These stages have been labelled the depth of the firm's openness. Additionally, all possible stakeholders with whom companies can collaborate throughout the production process have been defined as the width of the firm's openness.

This study econometrically identifies the factors that determine firm openness on the basis of industries and regions in Turkey. The study was conducted across 420 companies, which were among the largest 1000 companies in 2011 . The theoretical basis puts forward the characteristics related to the firm's internal and external environment as well as the firm's ability to collaborate as the determinants of firm openness. In the analyses, the effects of proximity and distancerelations between regions/provinces on firm openness were determined as well, and how much and in which direction these effects deviated from the general were observed.
\end{abstract}

\section{Keywords}

Open innovation, Firm depth, Firm width, Inbound open innovation, Outbound open innovation, Geographically weighted regression

\section{Introduction}

Open innovation is to purposefully enable knowledge inflow to and outflow from the firm in the process of innovation in order to accelerate the innovation accomplished within the firm. The concept of open innovation, which was first used by Chesbrough (2003), refers to, in essence, firms' opening their innovation processes outward. This method, which companies have increasingly begun to use in innovation management, is a result of the need to create

1 Ümit K. Seyfettinoğlu (Assoc. Prof. Dr.), Akdeniz University, Faculty of Economics and Administrative Sciences, Department of Economics, Antalya, Turkey. E-mail: umitk@akdeniz.edu.tr ORCID: 0000-0002-4782-0108

2 Corresponding author: Şebnem Arık (Dr.), Akdeniz University, Faculty of Economics and Administrative Sciences, Department of Economics, Antalya, Turkey. E-mail: sebnemarik@gmail.com ORCID: 0000-0002-1392-745X

3 Selim Çağatay (Prof. Dr.), Akdeniz University, Faculty of Economics and Administrative Sciences, Department of Economics, Antalya, Turkey. E-mail: selimcagatay@akdeniz.edu.tr ORCID: 0000-0002-5471-3474

To cite this article: Seyfettinoğlu, Ü., K., Arık, Ş., Çağtay, S. (2020). Determinants of industry and region based open innovation in Turkey. Istanbul Business Research, 49(1), 1-35. http://doi.org/10.26650/ibr.2020.49.0029 
a new value by blending technology developed inside and outside the company (Elmquist et al., 2009: 326). Chesbrough and Bogers (2014: 12) later defined open innovation as "an innovation process based on the management of knowledge flows across organizations, using pecuniary and non-pecuniary mechanisms in line with each firm's business model". Knowledge flow can take place in the form of knowledge inflow to the firm (inbound innovation) or knowledge outflow from the firm (outbound innovation) as well as in the form of bidirectional knowledge flow (inflow to - outflow from the firm).

Chesbrough (2003) argues that significant changes have been observed in the processes of developing new ideas and releasing them into the market, leading to the loss of the characteristic of the internal R\&D works as an important strategic asset. In this emerging picture, it is suggested that firms use their own internal ideas as well as external knowledge and develop their own technologies. Open innovation practices in a sense are becoming inevitable for an effective innovation process (Chesbrough, 2003:43-53).

In the period when Chesbrough (2003) first used the concept of open innovation, with this concept, he meant for firms to make more use of external ideas and technologies, and also to open the use of internally generated but unused ideas and developed technologies to other firms.

The traditional closed innovation model approach has gradually been weakened by the presence of abrasive factors (the increase of employee mobility, the presence of more qualified universities, the reduction of American hegemony and the increased accessibility of venture capital of newly established firms) experienced in the research and development process and changed the conditions for firms to be able to produce innovations (Chesbrough and Bogers, 2014: 18). In the closed innovation model, it is assumed that the innovation process should be controlled by the firm. However, firms have become more open to external knowledge with the increase in the mobility of the knowledge-producing employees and the development of the intellectual property rights as a result of changing social and economic conditions.

In the open innovation process, knowledge can be obtained from internal and external sources and the new technology can be included in the production process at different stages. Moreover, new technologies developed inside can be transferred to the market through licensing or spin-off ventures. Thus, the permeability of firm boundaries increases and it becomes possible for innovation to move much more easily between the internal R\&D process and the external environment (Elmquist et al., 2009: 327).

Chesbrough (2006: 2) defines the concept of open innovation as "purposive inflows and outflows of knowledge". This definition also takes into account the studies on spillovers resulting from firms' research and development investments in the related literature. The spillover effect refers to the inability of firms to predict the outcome of their R\&D investments 
and that the social benefit derived from R\&D investments is more than the private benefit of the firm that made the investment. The related literature emphasizes that the dispersion of knowledge is a cost element for the main company and cannot be controlled. In the open innovation model, this dispersion of knowledge is transformed into the knowledge input and output that can be controlled by the firm. Firms can develop processes to research and transfer external knowledge in order to incorporate them into their own innovation activities and also create channels to transfer the knowledge, which is their own production and is not used inside, to other firms. As a result, the knowledge qualified to be incontrollable and indeterminable before becomes transformed into determinable and controllable in the open innovation model (Chesbrough and Bogers, 2014: 11-12).

In the studies related to open innovation applications, it is revealed that the level of openness of firms is determined by a number of variables in the firm's own settings, in its external environment and in the collaborations it has established. The concepts of 'width' (stakeholders collaborated for open innovation) and 'depth' (level of collaboration) have been developed to describe the level of openness of firms (Laursen and Salter, 2006, 131-136). Internal characteristics include characteristics of firms' demographic structures and strategies. The number of employees employed, sales, profit, market share, age of the firm and the type of the firm's ownership (company type) are included in the demographic structure. The firm's strategic characterization includes strategic management, objectives or characteristics of its innovation strategy, and its organizational culture as well as its any other actions that may be related to its open innovation performance (Huizingh, 2011: 5).

The most obvious external characteristic is the industry in which the firm is located. Other external variables constitute firms' benefiting from different sources of information, access to technological opportunities, turbulence level and activities of other firms in the industry (Cohen and Levinthal, 1990; Lazzarotti et al., 2012; Huizingh, 2011).

Companies collaborate to take advantage of external information sources for reasons such as to reduce the cost of technological development, facilitate market access, benefit from economies of scale and save time for new product development (Tidd et al. 2005: 285). One of the main reasons for companies to gravitate towards open innovation is to reduce the risk and cost of innovation while another is the need for more skills, competence and creativity (Huang et al., 2009). The collaboration structure used to determine the level of firm openness consists of the following variables: Variables related to organizational structure, administrative actions, perspectives of collaboration (for example, employees' attitude towards teamwork and interaction of different units) and adoption of a certain intellectual property protection mechanism (Lazzarotti et al., 2012: 6). Administrative and organizational actions ensure that open innovation is maintained more easily and effectively (Lazzarotti et al., 2011:417). Some of these actions that are considered to facilitate open innovation practices are as follows: Top 
management to encourage employees to open innovation practices (Pisano and Vergant, 2008: 3), employment of a 'champion' employee directing the integration of external technology/ external knowledge (Chesbrough 2006), and both exploration and selection of potential collaborative partners and formal assessment of objectives and risks of collaboration (Huston and Sakkab, 2006).

The purpose of this study is to determine the extent to which firms are prone to innovation or how open they are to the innovation process in Turkey in the key industries of foods and beverages, textile, automotive, energy, paper, chemical, construction, metallic goods, plastic goods and mining. In other words, determination of the possible factors that may affect firms' openness in the mentioned industries constitutes the main objective. Here, the openness is handled as both depth and width. While factors affecting openness on the industrial basis will be found with these analyses, how these factors will differ among industries will also be revealed. Another aim of the study is to determine the factors that influence the firm's width and depth, and the interaction created by the spatial distance based on the provinces. In other words, the aim is to find out how spatial heterogeneity influences firms' approach to open innovation. Thus, it is aimed to prospectively determine the research areas related to the subject on the basis of region/province. Clues will be sought as to the determination of population, trade and financial flows that may result in outcomes caused by the spatial heterogeneity, and the industries in which they may emerge more dominantly. For the stated purposes, a field study was carried out in Turkey in 2011 covering 420 of the companies listed in the largest 1000 firms according to the turnover value by the Istanbul Chamber of Industry. Considering 'the positive effects of open innovation on the firm's innovativeness and economic performance', frequently mentioned in the relevant academic literature, it can be said that another important objective of this study is to develop policy recommendations based on empirical findings.

In the second part of the study, there is the literature section which gives the summary of the international studies conducted on the factors determining firm openness. The third part is the method section consisting of field work and econometric analyses. In the fourth part empirical findings are given, and in the last part the results are discussed and implications are given.

\section{Literature review}

In the relevant academic literature, it is indicated that the level of openness of firms is determined by a number of variables in the firms' internal environment, in their external environments and in the collaborations they have established (Lazzarotti et al., 2012; Lazzarotti et al., 2011; Huizingh, 2011; Laursen and Salter, 2006). For this reason, it is necessary to determine the extent to which firms are prone to innovation or how open they are to the innovation process, and the possible factors that may influence the openness of the 
firm. Table 1 provides the main characteristics of the empirical studies that focus on factors that determine firm openness.

Table 1

Summary of Empirical Studies Focus on Firm Openness Level

\begin{tabular}{|c|c|c|c|c|}
\hline Reference & Methodology & $\begin{array}{c}\text { Time } \\
\text { Period }\end{array}$ & Purpose & Industry Coverage \\
\hline Barge-Gil (2010) & $\begin{array}{l}\text { Panel } \\
\text { probability } \\
\text { model }\end{array}$ & $\begin{array}{l}2004- \\
2006\end{array}$ & $\begin{array}{l}\text { To examine the determinants of open } \\
\text { innovation strategies in the company's } \\
\text { perspective. }\end{array}$ & $\begin{array}{l}\text { Companies operating in } \\
\text { the Spanish manufacturing } \\
\text { industry ( } 3368 \text { companies in } \\
2004,3953 \text { in } 2005)\end{array}$ \\
\hline $\begin{array}{l}\text { Michelino et al. } \\
\text { (2014) }\end{array}$ & $\begin{array}{l}\text { Linear } \\
\text { regression }\end{array}$ & $\begin{array}{l}2008- \\
2012\end{array}$ & $\begin{array}{l}\text { To analyze the relationship between } \\
\text { firms' degree of openness and their } \\
\text { general condition, R\&D regulations } \\
\text { and financial performance. }\end{array}$ & $\begin{array}{l}126 \text { pharmaceutical } \\
\text { companies operating in } \\
\text { Europe and in the US }\end{array}$ \\
\hline $\begin{array}{l}\text { Lichtenthaler } \\
(2008)\end{array}$ & $\begin{array}{l}\text { Cluster analysis, } \\
\text { probability } \\
\text { model }\end{array}$ & & $\begin{array}{l}\text { To examine the firms' strategic } \\
\text { approaches to open innovation. }\end{array}$ & $\begin{array}{l}\text { Medium and large-scale, } \\
\text { technology-focused } 154 \\
\text { companies operating in } \\
\text { Germany, Switzerland and } \\
\text { Austria }\end{array}$ \\
\hline $\begin{array}{l}\text { Lazzarotti et al. } \\
\text { (2011) }\end{array}$ & $\begin{array}{l}\text { Cluster analysis, } \\
\text { ANOVA, } \\
\text { factor analysis, } \\
\text { hierarchical } \\
\text { regression }\end{array}$ & 2009 & $\begin{array}{l}\text { To examine the different models that } \\
\text { firms apply when opening out the } \\
\text { innovation process. }\end{array}$ & $\begin{array}{l}99 \text { companies operating in } \\
\text { the Italian manufacturing } \\
\text { industry }\end{array}$ \\
\hline $\begin{array}{l}\text { Schroll and Mill } \\
\text { (2011) }\end{array}$ & Cluster analysis & 2009 & $\begin{array}{l}\text { To investigate how and where open } \\
\text { innovation practices are used in } \\
\text { Europe. }\end{array}$ & $\begin{array}{l}180 \text { companies from } \\
\text { different sectors in } 24 \\
\text { European countries }\end{array}$ \\
\hline Mina et al. (2014) & $\begin{array}{l}\text { Hierarchical } \\
\text { Regression }\end{array}$ & 2010 & $\begin{array}{l}\text { To investigate how open innovation } \\
\text { practices in the service sector differ } \\
\text { from the manufacturing sector. }\end{array}$ & $\begin{array}{l}788 \text { companies from } \\
\text { different sectors in the UK }\end{array}$ \\
\hline $\begin{array}{l}\text { Van de Vrande et } \\
\text { al. (2009) }\end{array}$ & Cluster analysis & 2005 & $\begin{array}{l}\text { Focusing on open innovation practices } \\
\text { in SMEs, to investigate whether } \\
\text { there is a tendency to adopt the open } \\
\text { innovation model over time. }\end{array}$ & $\begin{array}{l}605 \text { small and medium- } \\
\text { sized companies from } \\
\text { the Dutch manufacturing } \\
\text { industry and service sectors }\end{array}$ \\
\hline $\begin{array}{l}\text { Seyfettinoglu and } \\
\text { Tasdelen (2014) }\end{array}$ & $\begin{array}{c}\text { Ordinary } \\
\text { least squares, } \\
\text { probability } \\
\text { and ordered } \\
\text { probability } \\
\text { models }\end{array}$ & 2014 & $\begin{array}{l}\text { To investigate the factors affecting } \\
\text { firm openness }\end{array}$ & $\begin{array}{l}146 \text { Food and Beverages } \\
\text { firms which were ranked } \\
\text { in } 2011 \text { among the first } \\
1000 \text { business enterprises } \\
\text { according to the report } \\
\text { of İstanbul Chamber of } \\
\text { Industry. }\end{array}$ \\
\hline
\end{tabular}

Barge-Gil (2010) examined the determinants of open innovation strategies from the firm's point of view. In the study, Spanish manufacturing industry company data from the years 2004-2006 was used. The openness used as a dependent variable was defined in two different ways, and the 'multinominal logit panel data model' was used to determine the effect of independent variables on the openness. The first openness criterion focused on how innovation was achieved, while the second criterion assessed subjective responses related to the importance of different sources of information. Independent variables used were the firm size, $R \& D$ intensity, dummy variable related to the technological structure of the industry in 
which the firm was located, share of exports in total sales, share of new product sales in total sales (radical innovation), orientation of the R\&D behaviour, cost and information barriers encountered in the innovation process, and dummy variable related to whether or not the firm was involved in a group. The results showed that the firms implementing open innovation had a smaller scale and a lower R\&D concentration than the firms implementing a semiopen strategy, but that they had a larger scale and a higher R\&D concentration than the firms implementing closed innovation.

Michelino et al. (2014) analyzed the relationship between firms' degree of openness and their general condition, $R \& D$ regulations and financial performance. To test the identified hypotheses, the sample consists of 126 drug companies operating in Europe and the US, with the highest expenditure on R\&D. The dataset obtained from these companies covered the years 2008-2012. The independent variables used were the firm size, age of the firm, closed R\&D expenditure per employee, per-employee income before tax and interest, asset yields and total market value of the firm. Inbound and outbound open innovation strategies were utilized as dependent variables. According to the results, open innovation practices were more common in small-scale and new biotechnology firms. It was also determined that internal $R \& D$ applications were substituted with the inbound open innovation and complementary to the outbound open innovation.

Lichtenthaler (2008) examined firms' strategic approaches to open innovation. The sample of the study consisted of 154 medium and large-scale companies in Germany, Switzerland and Austria. A cluster analysis was performed, and the Logit model was used in econometric analyses. The external technology acquisition and external technology exploitation were used as dependent variables. The independent variables were the R\&D density, radical innovation, product diversity, technological diversity, internal differentiation, presence of an institutional enterprise unit, dummy variables of country and industry, and revenues. The results of the cluster analysis showed that many firms still maintained a closed innovation approach. In addition, there was a positive relationship between the acquisition of external technology and the use of external technology. While the size of firm had a significant effect on openness, the industry in which the company was located had no effect on openness. Thus, it was found that the degree of openness of innovation process was mainly determined by individual decision mechanisms of the firm and was not related to sectoral characteristics. Moreover, it was determined that companies that implemented the open innovation strategy had a relatively higher profitability.

Lazzarotti et al. (2011) examined different models that firms apply when opening out the innovation process. Open innovation models were separated into four types - open innovation, closed innovation, integrated innovation, and specialized innovation. Whether different firmspecific features could be integrated into different open innovation models, and the effect of 
these different models in terms of innovation performance were examined. An analysis was conducted on data obtained from a survey conducted in 2009, on 99 companies operating in the Italian manufacturing sector. First of all, a cluster analysis was performed using the two indicators collaboration diversity and innovation stage diversity, which represented the degree of openness. At the next stage, whether or not these clusters differed in terms of firm-specific factors was investigated with an ANOVA analysis. Factor analysis was applied to the firmspecific factors. Finally, the relationship between the determined firm-specific factors and the two dependent variables, which were indicative of the level of openness, was examined. The firm-specific variables used were the purpose of collaboration, approach to innovation, organizational and managerial open innovation activities, R\&D intensity, firm size (revenues and the number of employees), sales revenues and asset yields (return on assets) representing the firm performance. In the first step of regression analysis, only the effect of the purpose of collaboration and approach to innovation variables on the dependent variables was analyzed; then, the analysis was re-modelled with the addition of the effect of R\&D intensity. According to the results, the innovation models at the two ends were more commonly applied. Open and closed innovation practitioners differed in terms of the approach to innovation, R\&D intensity, goals and organizational and managerial activities.

Lazzarotti and Manzini (2009) classified the open innovation practices into four groups - open innovation practitioners, closed innovation practitioners, integrated innovation practitioners and specialized innovation practitioners. The aim of the study was to investigate whether or not classified open innovation applications were being used by firms. In the sample of the study, 52 Italian companies operating in different sectors were used. Companies were classified according to open innovation strategies using data obtained from interviews made with companies. 12 firms were selected from the sample, and their firm characteristics and strategies were examined.

Schroll et al. (2011) investigated how and to what extent open innovation was used in Europe, and examined inbound and outbound open innovation practices. In the study, hypotheses about the effect of open innovation and internal R\&D activities were tested using the survey data in 2009 gathered from the sample of 180 firms operating in different industries, in 24 European countries. Cluster analysis was carried out in the study. Firms were divided into 3 categories, namely open, closed and semi-open, according to their degrees of openness. Inbound and outbound open innovation activities and R\&D intensity were used as variables. Also, according to innovation strategies, firms were classified as inbound open innovation, outbound open innovation, vertical integrated innovation, and mixed, and the R\&D intensity was examined in each strategy. According to the findings, $30.3 \%$ of the firms were quite open to innovation and $38.7 \%$ were semi-open. The inbound open innovation was more commonly used and this was explained by market failure. In addition, innovation strategies were found to be related to the $R \& D$ intensity. 
Mina et al. (2014) focused on the open innovation practices in service firms and investigated how their practice in this sector differed from the manufacturing sector. The data used was obtained from the survey conducted in 2010 to investigate the open innovation practices in the UK firms. The sample consisted of 788 companies from different sectors. The dependent variable used in the analysis was the level of open innovation activities. The open innovation activities were analyzed by separating them as formal, informal and total. The independent variables used in the first analysis were the firm size and age, internal $R \& D$ expenditures, the largest market of the firm (in terms of the type of sales revenue), intensity of competition, human capital, the effectiveness of the protection of intellectual rights, and the dummy variable showing whether the firm was a service company. In the second analysis, the marketbased knowledge and science-based knowledge sources in the open innovation activities were separated and included as independent variables. In the third analysis, when the role of service integration was assessed in manufacturing firms, the share of services in the firm's total revenues and the service component in the firm's innovative product were integrated into the independent variables. All analyses were performed using the hierarchical least squares method. According to the results, the service firms were more open to external knowledge than the production companies. The service firms used the informal open innovation practices more intensely than the formal practices, compared to the manufacturing firms. In addition, they attached more importance to scientific and technical knowledge than market knowledge.

Van de Vrande et al. (2009) investigated whether there was a trend towards adoption of the open innovation strategy over time, focusing on the open innovation practices of small and medium-sized firms. In particular, the differences between manufacturing and service firms, and medium and small firms were examined. In the study, survey data obtained from 605 small and medium sized firms in the Netherlands was used. The open-ended answers given to the questions were classified, and cluster analysis was carried out. The results showed that innovation in SMEs became increasingly open. While there was no significant difference between the open innovation practices in the manufacturing industry and service sectors, it was indicated that the medium-sized firms engaged more in open innovation practices than the small firms.

Seyfettinoğlu ve Taşdelen (2014) analyzed the effects of open innovation on firm performance in the Turkish Food and Beverages Industry. Firstly, interviews with 146 Food and Beverages firms which were ranked in 2011 among the top 1000 business enterprises according to a report from the Istanbul Chamber of Industry were carried out. Secondly, factor analysis was performed on the internal and external factors and cooperation capability variables which were assumed to affect open innovation, and the effects of these factors and similarity among firms in terms of the effects were evaluated. Thirdly, econometric analyses were carried out to reveal the impact of factors that are assumed to affect firms' openness, innovativeness and economic performance. 
This study differs from the above-mentioned literature in terms of handling open innovation empirically. Open innovation is included in terms of the 'depth' and 'width' dimensions; and according to the industry, factors that affect both dimensions are determined based on the firm characteristics. Here, the depth represents the stage where open innovation is observed in the process from production to marketing, while the width represents the type of stakeholders which collaborated. The factors assumed to affect the depth and width are similar to the independent variables used in the literature mentioned above. In addition, the effects of proximity and distance-relations between regions/provinces on firm openness were determined in the analyses using Geographically Weighted Regressions, and how much and in which direction these effects deviated from the general were observed.

\section{Methodology}

In this study cross-sectional econometric models using the least squares and geographicallyweighted regression methods were used to analyze the empirical relationships. The data set was obtained through a field study.

\section{Field Study}

One of the main objectives of the study was to determine the behaviour of the largest 1000 firms with respect to turnover (published by the Istanbul Chamber of Industry (ICO) in 2011), assumed to have a more professional and institutional structure towards open innovation. Six of these firms were located in Antalya and firstly a pilot application was conducted on these 6 firms and on other 24 in the Antalya Organized Industrial Zone. The firms belonged to various industries except automotive, mining and metallurgy.

The field study was made with a total of 420 firms falling within the largest 1000 in 20111. The sample's being limited to 420 could be considered to constitute an obstacle to an industry-based analysis. Considering that the number of food and textile companies in the total population was 157 and 149 respectively, it was seen that the sample volumes of these industries, which were 94 and 100 respectively, had statistically representative power (the sensitivity coefficient was taken as 0.06). In the other industries, based on expert opinions, the following classification was created and the sensitivity coefficient was increased to 0.07 to try to avoid the statistical representation problem. Distribution of the firms according

1 In the case where the total population volume was known, the $n=\frac{N t^{2} P Q}{N d^{2}+t^{2} P Q}$ formula was used for the determination of sampling. Here, $\mathrm{n}$ was the sample size, $\mathrm{N}$ was the population, $\mathrm{t}$ was the table value (taken as 2 for the level of error of 0.05$)$, $d$ was the sensitivity (taken as 0.04$)$, and P.Q was the mass variance $(0.5 \times 0.5$ was assumed - in homogeneous states). Therefore, the sample volume that would statistically represent the largest 1000 firms should have a minimum volume of 384 . 
to industries was given in Table 22 . The questionnaire was answered through face-to-face interviews and the answers were given on a 7-point Likert scale.

Table 2

Industrial Distribution of Firms

\begin{tabular}{lclcll}
\hline & Firms (\#) & Industry & & Firms (\#) & Industry \\
\hline $\mathbf{1}$ & 94 & Food industry & $\mathbf{7}$ & 23 & Paper industry \\
$\mathbf{2}$ & 100 & Textile industry & $\mathbf{8}$ & 34 & Chemical industry \\
$\mathbf{3}$ & 33 & Automotive industry & $\mathbf{9}$ & 11 & Wood work \\
$\mathbf{4}$ & 22 & Mining & $\mathbf{1 0}$ & 21 & Power tool production \\
$\mathbf{5}$ & 23 & Plastic goods production & $\mathbf{1 1}$ & 32 & Iron and steel industry \\
$\mathbf{6}$ & 17 & Metallic goods production & $\mathbf{1 2}$ & 10 & Machinery industry \\
& & & $\mathbf{N}$ & $\mathbf{4 2 0}$ & \\
$\mathbf{1}$ & 94 & Food industry & $\mathbf{4}$ & 54 & Mining and iron and steel industry \\
$\mathbf{2}$ & 100 & Textile industry & $\mathbf{5}$ & 61 & Plastic, metallic, electrical goods \\
$\mathbf{3}$ & 43 & Automotive and machinery industry & $\mathbf{6}$ & 68 & Woodwork, paper, chemical industry \\
\hline
\end{tabular}

\section{Econometric Analysis}

Variables used in the econometric models were selected/determined according to the results of factor analysis and were organized as discrete, sequential discrete and continuous variables. Since the field study data belonged to a single year, econometric analyses were estimated by cross-sectional models and the least squares and geographically-weighted regression method. To deal with heteroscedasticity problem White's heteroscedasticity consistent estimators were used.

The established econometric models shaped around a few main arguments. These can be summarized as 'the test of the presence of internal, external and collaborative variables that affect firm openness positively and/or negatively'.

Firm openness was addressed by two different variables, both depth and width. Therefore, two equations were predicted in order to be able to find the factors effective on the openness. While the depth indicator focused on the type of open innovation and the stage 3 in the process that the firm has undertaken, the width indicator covers the types of stakeholders that the firm collaborated with ${ }^{4}$. In the question form, the sum of the responses given by the firms in a 7-point Likert scale to each option under the depth and width indicators gave the score of firm depth and width levels. In this model, on the right-hand side of the equation were the internal variables, external variables and collaboration variables, and the list of these variables was given in the Appendix. Variables based on the internal factors were grouped

2 The questionnaire form used in the survey can be provided upon request.

3 Idea generation, idea development, experience, engineering, manufacturing (output), commercialization.

4 Universities and research centres, innovation intermediaries, public agencies/institutions, customers (e.g. retailers), input suppliers, consumers, competitors and companies operating in other sectors. 
under the groups of firm strategy, innovation strategy, innovation resources and competences. While demographic characteristics of the firm were also considered as an internal factor, the relevant data was obtained from the ICO. The collaboration variables were grouped into four sub-groups: organizational and managerial actions, collaboration structure, organizational and managerial interventions, and mechanisms of intellectual property protection. Finally, variables based on the external factors were given under the 'business environment'. Equations were estimated separately for each industry.

\section{Geographically-Weighted Regression (GWR) Analysis}

The GWR technique is used in estimating the relationship between variables showing differences between locations. Hence the impacts of geographic externalities and spatial heterogeneity are included in estimated coefficients. The global regression model is generally expressed in eq. (1). The GWR technique improves the traditional regression framework defined by eq. (1) by estimating local variables instead of global variables. The GWR model is generally expressed as eq. (2):

$$
\begin{aligned}
& y_{\mathrm{i}}=\alpha_{0}+\sum_{k} a_{\mathrm{k}}+x_{\mathrm{ik}}+\varepsilon_{\mathrm{i}} \\
& y_{\mathrm{i}}=\alpha_{0}\left(u_{\mathrm{i}}, v_{\mathrm{i}}\right)+\sum_{k} a_{\mathrm{k}}\left(u_{\mathrm{i}}, v_{\mathrm{i}}\right) x_{\mathrm{ik}}+\varepsilon_{\mathrm{i}}
\end{aligned}
$$

In eq. (2), $\left(u_{\mathrm{i}}, v_{\mathrm{i}}\right)$ denotes the coordinates of $i$, while $a_{\mathrm{k}}\left(u_{\mathrm{i}}, v_{\mathrm{i}}\right)$ denotes the value of the $a_{\mathrm{k}}(u, v)$ continuous function at the point $i$. In this case, it is provided that the parameter values have a continuous surface, and the measurements related to this surface are made for specific points that show the spatial diversity of the surface. Thus, the GWR equality is an enriched version of the global regression equation in which the parameter surface is assumed to be equal within the space and provides a measure of the existing spatial differences (Fotheringham et al., 1998: 1907). In the calibration of the GWR model, it is assumed that when $a_{\mathrm{k}}\left(u_{\mathrm{i}}, v_{\mathrm{i}}\right)$ is estimated, a datum closer to the point $\mathrm{i}$ has more influence than a datum at a farther point than this point. In this context, the Weighted Least Squares method provides a useful basis for understanding the working principles of the GWR method. In the GWR method, any observation is weighted by considering its geographical proximity to the point $i$; as a result, its weight value is not equal in calibration and varies according to the point $i$. In this context, the GWR estimator is algebraically expressed as in eq. (3). In eq. (3), $W\left(u_{\mathrm{i}}, v_{\mathrm{i}}\right)$ is an $\mathrm{n} \times \mathrm{n}$ matrix whose non-diagonal components are values that show 0 and whose diagonal components are values that show the geographical weights of the point $i^{5}$.

$$
\alpha_{0}\left(u_{\mathrm{i}}, v_{\mathrm{i}}\right)=\left(X^{\mathrm{t}} W\left(u_{\mathrm{i}}, v_{\mathrm{i}}\right) X\right)^{-1} X^{\mathrm{t}} W\left(u_{\mathrm{i}}, v_{\mathrm{i}}\right) y
$$




\section{Econometric Findings}

\section{Industry-Specific Firm Openness}

The empirical results of the econometric estimates are given in Tables A1 and A2 in the Appendix, and these tables respectively show the variables 6 that were effective on the firm depth (nature and stage of collaboration) and width (type of stakeholder). The adjusted $\mathrm{R}^{2}$ of the estimated models varied between 0.51 and 0.81 in the first table and 0.33 and 0.71 in the second table. While the lowest explanatory power for the depth indicator was obtained for the plastic, metal and electrical goods manufacturing industries, the highest explanatory power was obtained for the textile industry. The lowest and the highest explanatory power for the firm width were achieved for the mining, iron-steel and food industries, respectively. Definitions of the explanatory variables given in these tables were given in the Appendix.

Figures 1 and 2 show, comparatively between the industries, the factors affecting the types of stakeholders in which the firms collaborated and the nature and stage of the collaboration they carried out with these stakeholders. Different colours in the figures refer to different industries, and the higher the number of colours vertically, the higher the number of industries in which the related factor is effective.

A result that can be inferred from these two figures is the fact that the factors that motivated collaboration had a positive impact on the firms' openness in the food, textile and paperchemical-wood industries, while they had no effect on the firm openness in the plastic-metalelectrical goods industries.

Strategies developed by companies internally influence especially firms' collaboration nature. However, this effect may be partially negative. Protection by intellectual property rights positively affects both the type of stakeholder and the nature of collaboration, especially in the food and plastic-metal-electrical goods industries. There is no effect on depth and width of intellectual property rights in the textile, mining, iron-steel and automotive-machinery industries. Organizational and managerial interventions positively affect both the types of stakeholders which collaborated as well as the nature of collaboration in the industries of plastic-metal-electrical goods, mining, iron-steel and chemical-paper-wood industries. The industry where these interventions are not at all effective is the automotive-machinery industry. It was also seen that these interventions influenced only by the type of stakeholder in the food industry and only the quality of collaboration in the textile industry.

6 A factor analysis was conducted to construct the independent variable from the indicators (each one corresponds to a question in the survey) in the subgroups based on the total for Turkey and industries. Here, the answers were in the 7-point likert scale and the independent variables were formed by taking the average of the questions collected under a factor statistically. The independent variables were then indexed to 100 , with a maximum value of 100 . Since the number of factors for each industry in subgroups was not equal, every variable seen in the list was not used as an independent variable for each industry. 
It is observed that the communicative and individual talents of the firms are not very determinative for firm openness. The conditions that determine the business environment cause a negative impact on the type of stakeholder in the food and chemical-paper-wood industries, and a negative impact on the quality of collaboration in the plastic-metal-electrical goods and automotive-machinery industries.

As an open innovation strategy, inbound orientation positively affects firm width except the plastic-metal-electrical goods and automotive-machinery industries. The inbound orientation also positively affects the quality of collaboration in the food and paper-chemicalwood industries. It is important to note here that the open innovation strategy, that is, the presence of an open innovation synchronously both outbound and inbound has a negative effect on width (mining, iron-steel, and paper-chemical-wood) and depth (mining, and ironsteel) in some industries.

Lastly, the first of the two points to be noted is that organizational focus always had a negative impact on either width or depth in the industries other than the plastic-metalelectrical goods and paper-chemical-wood industries. The second is that market and market place management had a negative impact on the types of collaboration of industries other than the food and textile industry. 

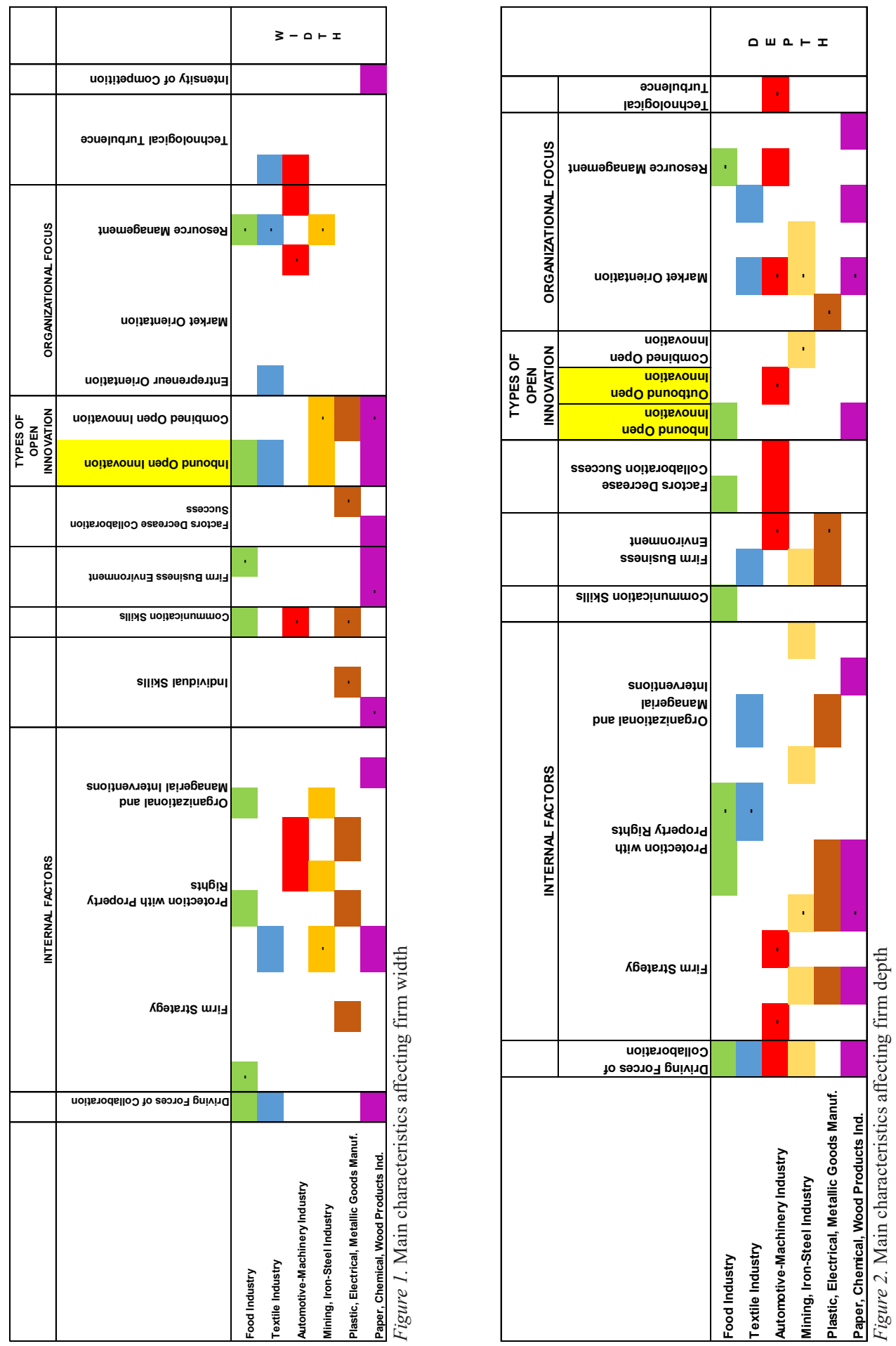


\section{Firm Openness Based on Regions}

The possible effects - created by the positive and negative externalities, which can be formed by neighbourhood relationships and distances between provinces, and the heterogeneity resulting from the geographical conditions - on the relationship between the dependent-independent variables can be estimated by the spatial econometrics. In this section, the geographically-weighted regression technique is used to model the mentioned effects.

Table 3 gives the global variables that are statistically significant on firm depth across Turkey. The driving forces of the inter-firm collaboration previously shown in Table $3(\mathrm{X} 1)^{7}$, the firms' being focused on new products and services (X2_2), the organizational and managerial interventions to support the initiation of the innovation process at the firm (X5 and X6), the differences in technological competence and business culture among stakeholders, and the reluctance to use information produced by different firms (X10_1), and finally, the inbound inter-firm innovation activities (X11) are observed as the global variables that increase firm depth. Among these variables, the most effective one is the inbound innovation activities. The outbound innovation activities (X12), the possession of a broad market and product portfolio at the national level (X3_2), and the rapidly changing technology and dependency on it (X15_1) have been found to have a negative effect on firm depth.

Table 3

Local Factors Affecting Firm Depth

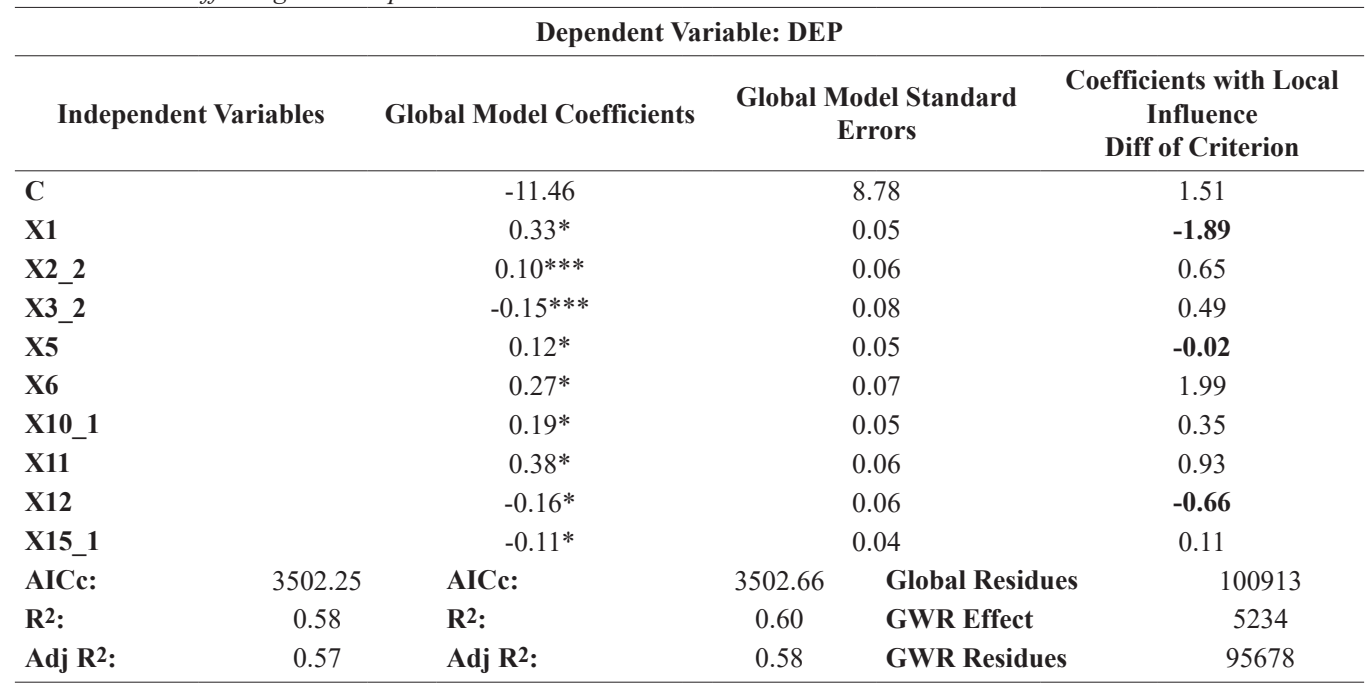

$*, * *, * * *$ At the statistical significance level of $0.01,0.05$ and 0.10 , respectively.

The global model estimation with the local prediction of some variables presents test statistics that offer an increase in the model's explanatory power. The decrease in the AICc on the right in the bottom rows of Table 3, the increase - although a small amount - in the adjusted $\mathrm{R}^{2}$ and the

7 Definitions of independent variables (X) are given in the Appendix. 
GWR residuals' being lower show that the local estimates will give a better result. The variables that take negative values in the last column of Table 3 indicate which variables have a varying effect on the basis of provinces. (X1), (X5) and (X12), are among these variables whose local effects are varying. In other words, the coefficients of the variables outbound innovation (X12), the factors that play a driving role on the inter-firm collaboration (X1), and the intervention of the firm for initiation of the innovation process (X5) vary across the provinces. The coefficients of the variables that vary across provinces are given on the maps ${ }^{8}$. On the maps, the value of the coefficient diminishes from dark to the light colour, and the numbers on the provinces represent the plate numbers of the provinces. Plate numbers are defined in Appendix Table A3. Also the distribution of the provinces in the geographical regions is shown on Maps A1 and A2. Map 1 reflects the local effects of factors that play a driving role on the inter-firm collaboration. It is seen that these factors are more effective especially in the firms in the Aegean, Inner Aegean, Marmara and Thrace regions. The provinces where these factors have the lowest relative effect are in the Central Anatolia and Mediterranean regions. The difference between the maximum and minimum effect is 0.18 units for this variable.

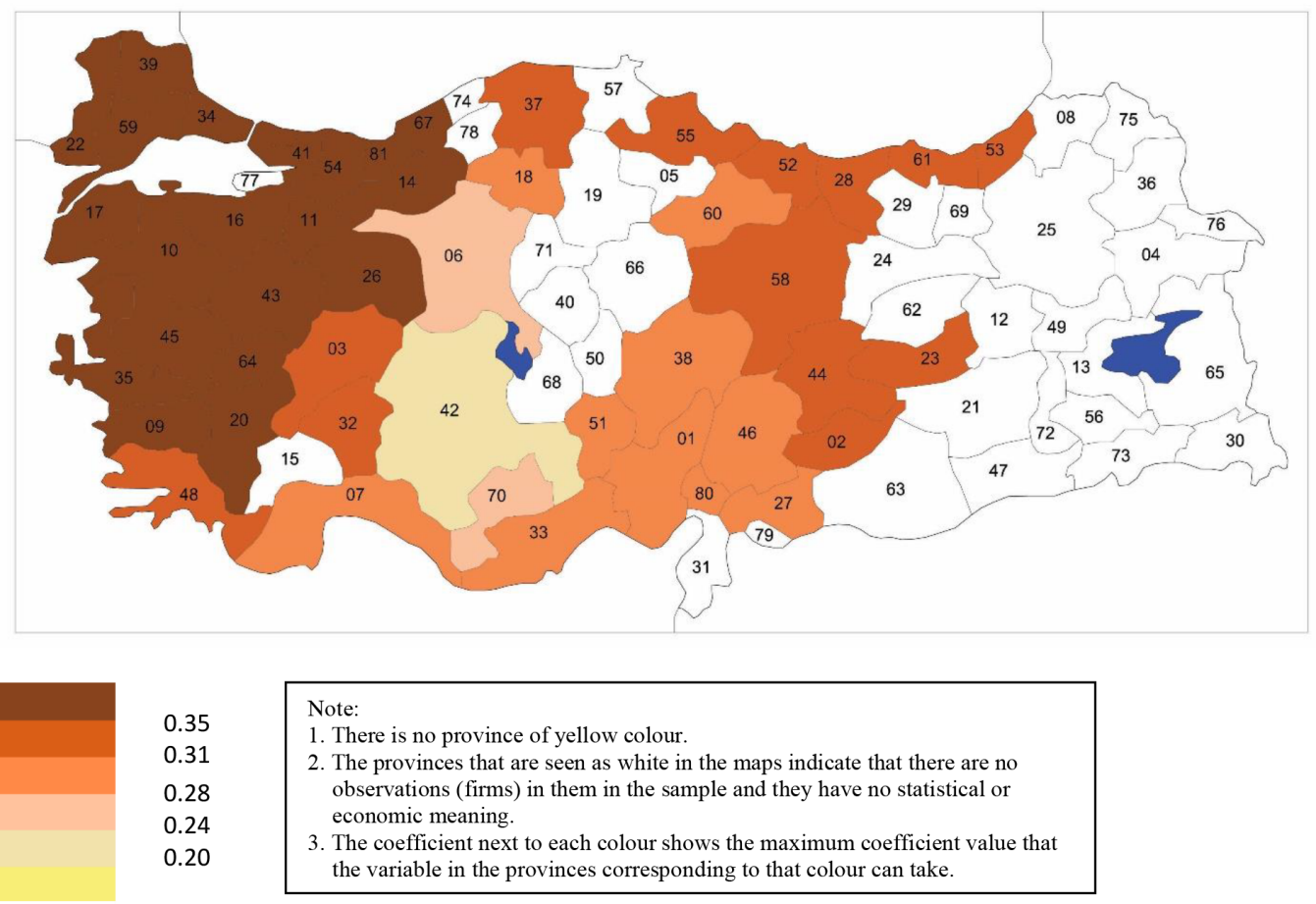

Map 1. Local Effect Distribution of Factors Playing a Driving Role on Inter-firm Collaboration (X1)

8 The maps of all variables with local effects and the provincial estimate powers $\left(\mathrm{R}^{2}\right)$ of local models can be given to readers who require. 
It is seen that the firm intervention variable for initiating the innovation process is more effective in the firms in the Aegean, Inner Aegean, Marmara, Thrace, and Western Black Sea regions. The provinces where these factors had the lowest relative effect are in the Mediterranean, apart from Antalya and the Middle Eastern Anatolia. The difference between the maximum and minimum effect is 0.12 units for this variable. The companies for which the outbound innovation reduced the firm depth the most are the ones in the Antalya, Aegean, Inner Aegean, Marmara, Thrace and Western Black Sea regions. The provinces on which this variable had the lowest relative effect are the ones in the Eastern Mediterranean, Middle Eastern Anatolia and Eastern Black Sea regions. The difference between the maximum and minimum effect is 0.17 units for this variable.

Table 4 gives the global variables that are statistically effective on the firm width across Turkey. The driving forces of the inter-firm collaboration (X1), the protection of companies by trade secrets and confidentiality agreements (X4_1), the organizational and managerial interventions to support the initiation of the innovation process at the firm (X6), the differences in technological competence and business culture among stakeholders, and the reluctance to use information produced by different firms (X10_1), the inbound inter-firm innovation activities (X11), the firms' getting organized towards entrepreneurs (X14), and finally, the rapid technology change (X15_2) are observed as the global variables increasing firm width. Among these variables, the most effective one is the inbound innovation activities as in the firm depth. The strategies of the firm to be a pioneer in technology, to use flexible technologies and to turn to radical innovations (X2_1), the lack of mutual interest and trust among stakeholders, and inability to establish effective cooperation (X10_2), and the outbound innovative activities (X12) have been found to have a negative effect on firm width.

Table 4

Local Factors Affecting Firm Width

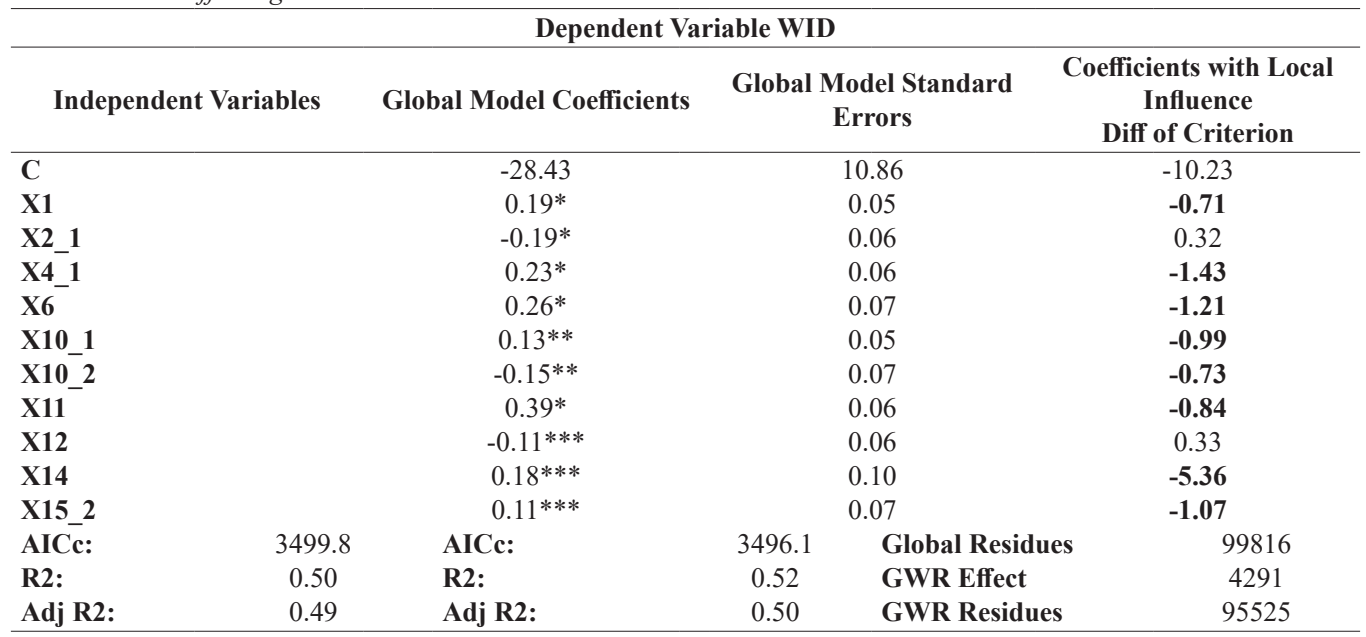

$*, * *, * * *:$ At the statistical significance level of $0.01,0.05$ and 0.10 , respectively. 
The global model estimate, again, with the local prediction of some variables presents test statistics offering an increase in the model's explanatory performance. The decrease in the AICc on the right in the bottom rows of Table 4, the increase - although a small amount - in the corrected $\mathrm{R}^{2}$ and the GWR residuals' being lower show that the local estimate will give a better result. When we look at the rightmost column of Table 4, it is observed that the variables (X1), (X4_1), (X6), (X10_1), (X10_2), (X11), (X14) and (X15)_2 have locally varying effects. To say it more clearly, the coefficients of the variables of the factors that play a driving role on the inter-firm collaboration (X1), the protection of companies by trade secrets and confidentiality agreements (X4_1), the organizational and managerial interventions to support the initiation of the innovation process at the firm (X6), the lack of mutual interest and trust among stakeholders, and inability to establish effective cooperation (X10_2), the inbound inter-firm innovation activities (X11), the firms' getting organized towards entrepreneurs (X14), and finally, the rapid technology change (X15_2) vary among the provinces. The coefficients varying between provinces according to variables are also presented on Maps 2 and
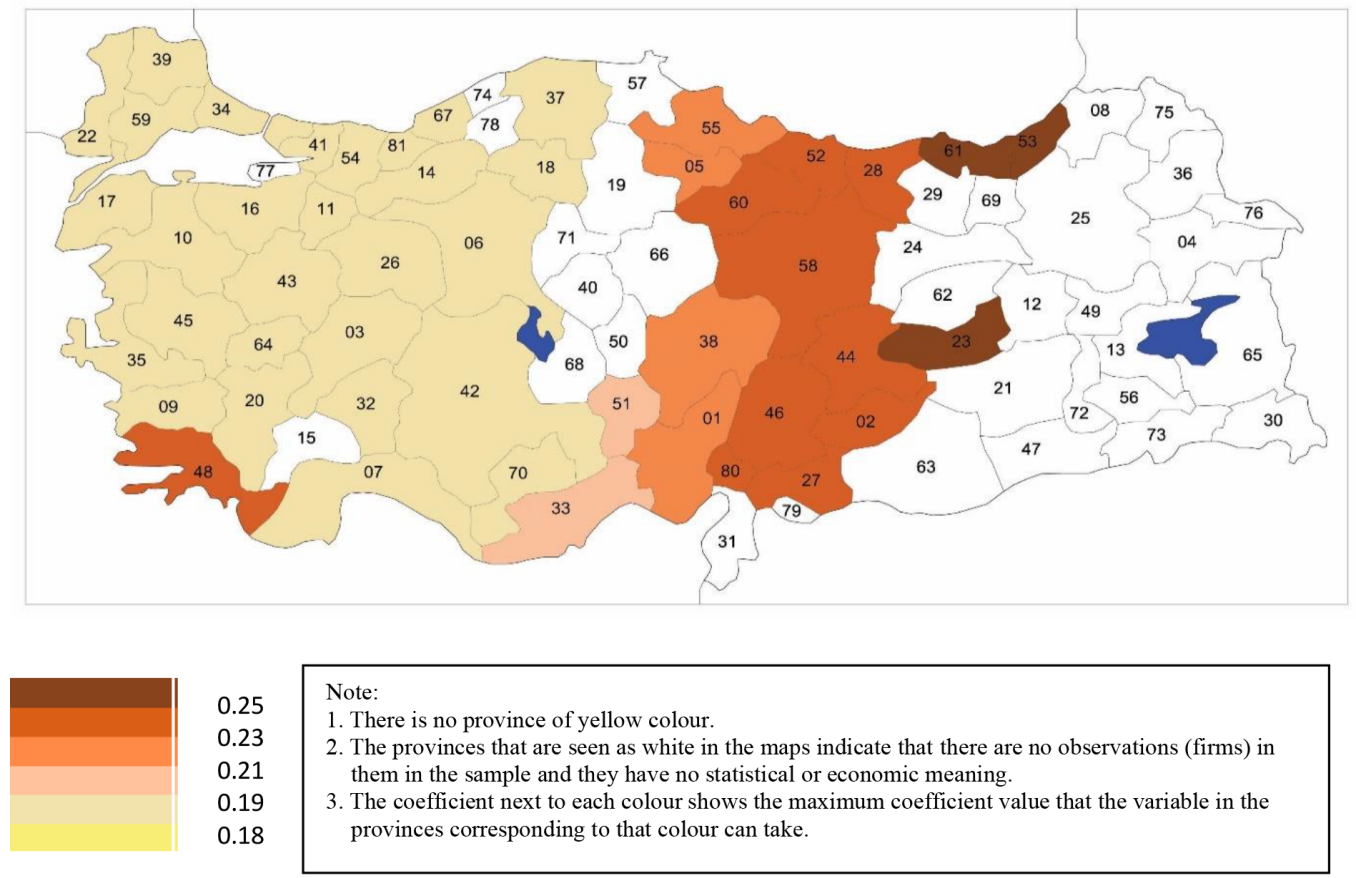

Map 2. Local Effect Distribution of Factors Playing a Driving Role on Inter-firm Collaboration (X1)

The effects of the protection of the firms by trade secrets and confidentiality agreements on width are high in the Marmara except Balıkesir, Trakya, and West Black Sea regions. Especially in Muğla, Eastern Mediterranean, Middle Eastern Anatolia, and Eastern Black 
Sea, this effect is very low. The difference between the maximum and minimum effect is 0.10 units for this variable.

The impact of organizational and managerial interventions supporting the initiation of the firm's innovation process on firm width is high in the Eastern Mediterranean and Eastern Black Sea, Middle East, and Muğla regions. In the Aegean, Inner Aegean, Western Mediterranean, Marmara, and Thrace regions, the effect is low. The difference between the maximum and minimum effect is 0.12 units for this variable. A similar effect in terms of effects on provincial basis can be seen on the effects of the uncertainty in consumer preferences and the rapid change factor on firm width.
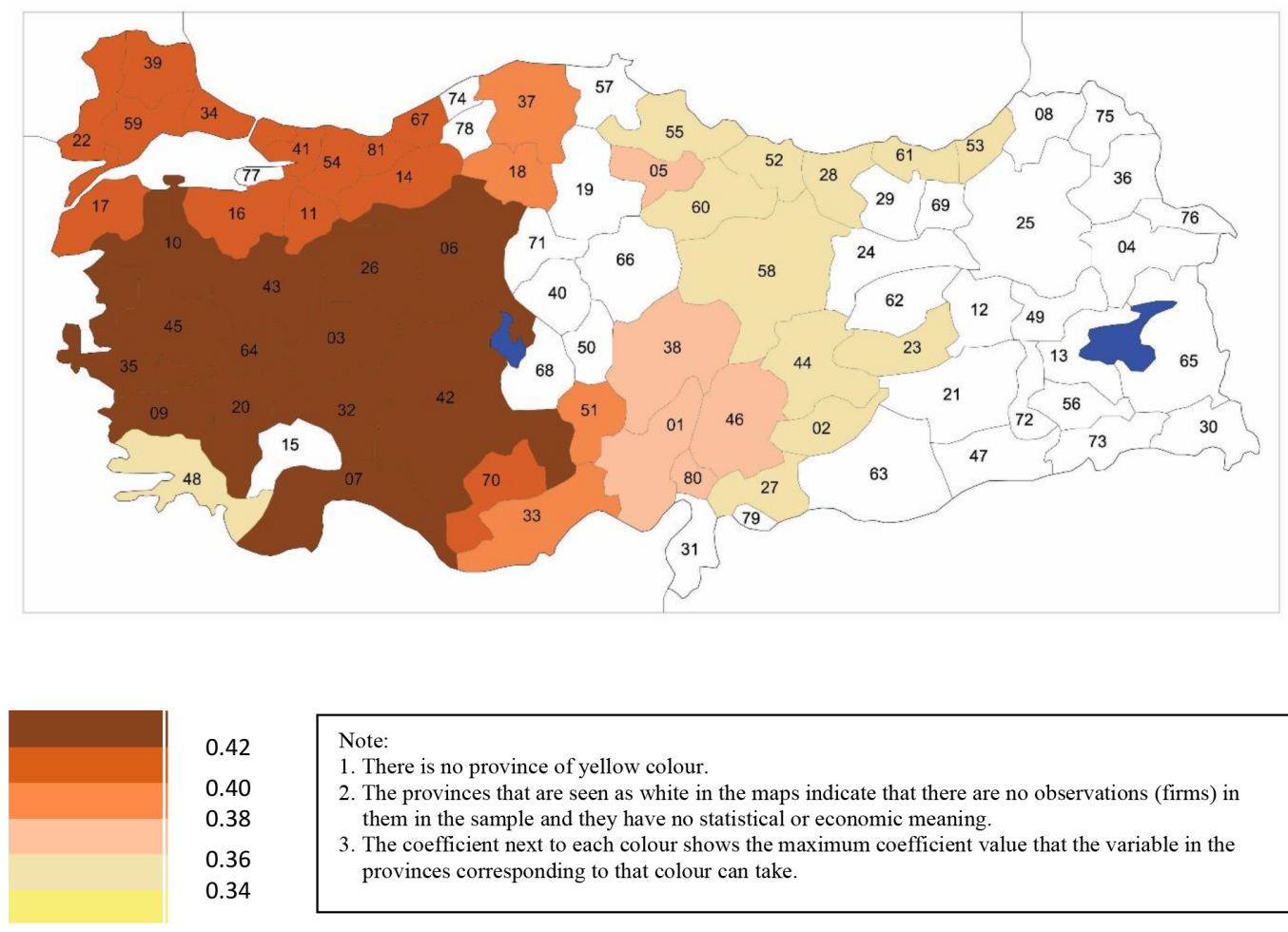
0.42
0.40
0.38
0.36
0.34

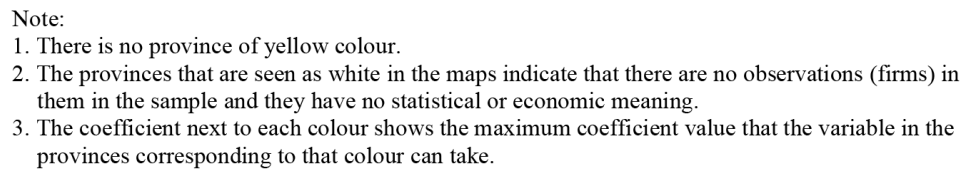

2. The provinces that are seen as white in the maps indicate that there are no observations (firms) in them in the sample and they have no statistical or economic meaning.

3. The coefficient next to each colour shows the maximum coefficient value that the variable in the provinces corresponding to that colour can take.

Map 3. Local Effect Distribution Inbound Open Innovation in Firms (X11)

Map 3 gives the local effect distribution of the inbound innovation (X11) in the firms. Here, the effect is decreasing from the west to the east. This effect distribution also applies to the uncertainty in consumer preferences and to the rapid change factor (X10_1) and mutual interest and lack of confidence between stakeholders (X10_2). In addition, the local effect of the uncertainty in consumer preferences and the rapid change factor are higher in the Aegean region than in the Marmara region, and it is seen that the Eastern Mediterranean and the 
Middle-Eastern Anatolia are the regions where the local effect distribution of the inbound innovation is the least effective. It is observed that the highest and the lowest coefficient differences are $0.11,0.10$ and 0.10 units for three variables, respectively.

\section{Conclusion}

This study aimed to measure the level of openness of the firms and to determine factors that affect openness in major industries such as the food and beverage, textile, automotive, energy, paper, chemical, construction, metallic goods, plastic goods and mining, listed in the largest 1000 companies in Turkey in the 2011 reported by the Istanbul Chamber of Industry. The openness of the firms, in other words, their tendency towards open innovation, was measured by the intensity of the indicators of depth and width. Factors affecting the firm openness were examined separately for each industry and province.

The intellectual property protection mechanisms such as the driving forces of collaboration in the food industry, design, multi-stage production processes and delivery times; the organizational and managerial activities on collaboration; the communication capabilities between functional units and the inbound innovation activities were the factors that positively affected the width of the company. Company strategies such as focusing on technological leadership and radical changes and the rapid changes in consumer needs and preferences within the industry to which the company belonged were the factors that negatively affected the width.

Factors that increased the width of a firm in the textile industry were as follows: The driving forces of the firm such as sharing the innovation risks and cost by improving its creative capacity, firms to have a wide market and product portfolio at the international level and the prevalence of their inbound open innovation activities. In addition, the entrepreneurial orientation and the rapidly changing and highly beneficial technology in the industry were also positively affecting the width.

In the automotive-machinery industry, firm width was positively affected from the organizational and managerial interventions and activities that support the innovation process, from the efforts made in resource management to avoid the imitation and detection of resources by competitors, and from the opportunities provided by rapidly changing technology in the industry. However, it was adversely affected by the lack of collaboration and interaction among different units in the course of innovation activities. In addition, factors such as the efforts made to make it difficult for other firms to obtain the same resources in the sector and the consolidation of some of the resources to increase productivity were emerging as factors that reduced the width. 
The administrative interventions and actions in order to support and coordinate the technological cooperation with stakeholders in the mining-iron-steel industry had an intensifying impact on the firm width in this industry. The width of the firm increased through inbound open innovation. As the international product and market portfolio of these firms increased, the width of the firm decreased. The tendency to protect resources and resource compositions from competing companies through combined (two way 9 ) open innovation activities negatively affected the width.

In the plastic-metallic-electrical goods industry, there was a positive relationship between the firm width and the new market-oriented and product-oriented firm strategy. It was determined that in this industry, the intellectual property protection mechanisms used, the organizational and managerial activities put forward in terms of collaboration, and the combined open innovation practices had a positive effect on firm width. In this industry, the width was adversely affected from the factors such as the coercive and creative goals for staff and the resources allocated for professional development of the staff, the communication skills between units in innovation activities and the lack of trust and interest between stakeholders, and the lack of an effective collaboration environment.

In the paper-chemical-wood industry, the driving forces and managerial activities for collaboration in the innovation activity and having a wide product and market portfolio at the international level were the factors that positively affected the width. Moreover, in this industry, the fact that technologies are protected by intellectual property rights and the reduction of scale economies arising from $R \& D$ increased the level of width. The results show that the differences in the business culture and management style among the stakeholders, which are among the factors that reduce the success of the collaboration, and the reluctance to accept the technology produced outside the company had a positive effect on the width. The inbound open innovation and the intensity of competition increased the width. In the paper-chemical-wood industry, the capabilities of the personnel working on the technological innovation, the rapidly changing needs of the customers in the industry and the difficult-topredict structure of this change reduced the firm width. In addition, the negative impact of the combined open innovation activities on the width was also detected.

Some of the variables affecting firm openness varied across the provinces. Of these variables, the factors motivating collaboration were effective on the intervention of the firm for innovation and the inbound type of open innovation collaboration, i.e., on the firm depth. It is seen that all these variables were more effective in the inner Aegean, Aegean, Marmara and Thrace provinces. The effect was gradually decreasing to the east. In general, it is seen that the impact size was growing in the framework of a neighbourhood. This result can be thought of as that the geographical proximity/distance created an externality. It is necessary

9 The inbound and outbound open innovations to take place together. 
also to look at the movements of population and trade among the provinces in order to strengthen this thinking.

The variables, which were effective on the firm width, i.e., the type of stakeholder, but in which this effect varied among the provinces, were the factors that play a driving role on collaboration, the protection of companies by trade secrets and confidentiality agreements, the organizational and managerial interventions that support the initiation of the innovation process in the firm, the lack of mutual interest and trust between stakeholders, the interfirm inbound innovation activities and finally, the rapid technological change. The vertical patterns affecting the firm depth were also observed among the variables affecting the firm width. Among these, the effects of the factors that play a driving role on collaboration, the organizational and managerial interventions that support the initiation of innovation in the firm, the lack of mutual interest and trust among stakeholders and the uncertainty in consumer preferences were increasing from west to east. The provinces with the greatest effect were in the Eastern Mediterranean, Middle Eastern Anatolia and partly Eastern Black Sea regions. The effects of variables; rapid technological change and the inter-firm inbound innovation activities were increasing in the opposite direction. Provinces in the Eastern Mediterranean, Middle Eastern Anatolia and partly Eastern Black Sea regions had the lowest relative effect.

The findings obtained from this research and the results based on these findings made it possible to make some suggestions and implications for relevant public institutions, private sector actors and related researchers.

The first implication for researchers is the necessity for conducting studies with largesamples, targeting each sub-sector in order to comprehensively investigate the internal and external dynamics and obtain concrete and focused results related to open innovation. The second implication for this audience is the necessity for the simultaneous examination of vertical and horizontal relationships within the sector while undertaking studies focusing on the sub-sector.

The most important inference for the public sector is that the public sector should play a leading and facilitating role in the preparation of the environment necessary for the inclusion of consumers in the innovation process, especially in demand-pull sectors such as food and textile. The public sector's implementation of incentive policies on the use of intellectual property protection tools, which positively impact firms' economic and innovation performance, is seen as another task for the public sector. Another implication that concerns the public sector is the firms' ability to closely follow the other companies in the sector that are very important for the innovation activities of the firms and, outside the sector, to monitor the results of university research outcomes and the policies of the public to determine their own strategies. Preparing the institutional structure to facilitate this follow-up, monitoring and encouraging the industry and commerce chambers and associations in this direction by public authority 
will make it easier for companies to accomplish these pursuits. Although university-industry collaboration has developed in recent years, it is obvious that this collaboration in Turkey is far behind that it is developed countries. Ensuring the university-industry collaboration is indispensable for the success of innovation. With different policy and non-policy instruments, the public sector must undertake the responsibility of developing mechanisms to establish this collaboration.

The private sector should educate their employees about innovation and the positive effects it provides, convince their staff that the innovative behaviour is part of the company's culture, and ensure the continuity of those trained employees in the firm.

The increasing technology development costs, the shortened product life span and the consequent decrease in product revenues have led private sector firms to open their innovation processes out of the firm. In addition, the emerging innovation risks and costs push firms to open out. In other words, open innovation may provide a solution to all these problems mentioned above. At this point, private sector representatives, civil society and professional organizations should raise awareness and perform orientation activities.

It is concrete with the empirical findings that there is a relationship between firm policies and practices and the level of implementation of open innovation in the process. In this case, it is possible and recommended for companies to develop more targeted strategies for open innovation applications. Parallel to this, it is also suggested that firms should not implement open innovation in more than one stage/level in the process, which is an implication to avoid reduction in efficiency.

The impact of open innovation on the firm's economic performance can be direct or indirect (through innovative performance), depending on the industry under review. In this case, the positive effect on economic performance in short or medium/long term should be grasped by the firms, should be a desired target and the company strategies should be determined accordingly. At this point, it is important to know, and explain to the firm, the difference between the open innovation stages/levels such as idea development, commercialization and so on, and the dynamics facilitating these. The best example of this is the need to know that the economic effects of open innovation initiatives taken regarding commercialization are not independent from market conditions. The desire for a radical innovative change is found to be a factor that motivates firms for open innovation and is common and important among industries. It becomes a necessity for the firms to investigate the determination and feasibility of the fundamental innovative change in question. Only then will the correct strategy be adopted.

It has been observed that the two partnerships, which do not depend on the industry and have a positive impact on economic performance, have been established with universities 
and input suppliers, and this has been found to be at the level of idea development. What is noteworthy is that these collaborations primarily have a positive impact on the innovative performance. Therefore, this finding gives clues to both public and private sectors about the issues that should be focused in the short-term and the points where the facilitating and disseminating instruments should be employed.

A subject that concerns the public, private and all actors regarding the issue is the commonality of the lack of mutual trust and common interest among stakeholders, which exists among firms and is observed in all industries. At this point it is imperative to prepare and implement educational programs that are pursued and encouraged under the initiative of the public sector and/or carried to the private sector agenda with policies and carried out by researchers. It will be useful for these programs to focus on issues of introducing to the business life, adding and transforming into economic returns the differences in the stakeholders' culture of doing business, and concepts such as positive externalities, clustering, space and scale economies created by sharing knowledge produced by one another. From here, it is important to develop strategies so that the targets such as the protection of resources common to all companies, avoiding the detection and imitation of them by the competitors, and an intra-firm productivity and efficiency increase can be achieved through industrial joint behaviours. This behaviour will undoubtedly affect the behaviour of medium and small sized firms over time.

Finally, it may be useful for the public sector to create the industrialization plan by taking into account the industry-based geographic efficiency differences of the horizontal and vertical interaction and collaboration, and to handle the private sector incentives within this framework.

Peer-review: Externally peer-reviewed.

Conflict of Interest: The authors have no conflict of interest to declare.

Grant Support: The authors declared that this study has received no financial support.

\section{References}

Barge-Gil, A. (2010). Open, semi-open and closed innovators: Towards an explanation of degree of openness. Industry and Innovation, 17(3), 577-607.

Chesbrough, H. (2003). Open innovation: The new imperative for creating and profiting from technology. Boston: Harvard Business School Press.

Chesbrough, H. (2006). Open business models: How to thrive in the new innovation landscape. Boston: Harvard Business School Press.

Chesbrough, H., \& Bogers, M. (2014). Explicating open innovation: Clarifying an emerging paradigm for understanding innovation. In H. Chesbrough, W. Vanhaverbeke \& J. West (Eds.), New Frontiers in Open Innovation (pp. 3-28). Oxford: Oxford University Press. 
Cohen, W. M., \& Levinthal, D. A. (1990). Absorptive capacity: A new perspective on learning and innovation. Administrative Science Quarterly, 35(1), 128-152.

Elmquist, M., Fredberg, T., \& Ollila, S. (2009). Exploring the field of open innovation. European Journal of Innovation Management, 12(3), 326-345.

Fotheringham, S., Charlton, M., \& Brunsdon, C. (1998). Geographically weighted regression: A natural evolution of the expansion method for spatial data analysis. Environment and Planning, 30, 1905-1927.

Huang, Y., Chung, H., \& Lin, C. (2009). R\&D sourcing strategies: Determinants and consequences. Technovation, 29, 155-169.

Huizingh, E.K.R.E. (2011). Open innovation: State of the art and future perspectives. Technovation, 31(1), $2-9$.

Huston, L., \& Sakkab, N. (2006). Connect and develop. Inside Procter and Gamble's new model for innovation. Harvard Business Review, 85, 58-66.

Laursen, K., \& Salter, A. (2006). Open for innovation: The role of openness in explaining innovation performance among U.K. manufacturing firms. Strategic Management Journal, 27, 131-150.

Lazzarotti V., \& Manzini, R. (2009). Different models of open innovation: A theoretical framework and an empirical study. Journal of Innovation Management, 13, 1-22.

Lazzarotti, V., Manzini, R., \& Pellegrini, L. (2011). Firm-specific factors and the openness degree: A survey of Italian firms special issue OI. European Journal of Innovation Management, 14, 412-434.

Lazzarotti, V., Garcia, M., Manzini R., \& Sanchez, M. (2012). The open innovation in practice: A survey in the food \& drink industry. The XXIII ISPIM Conference, 17-20 June, Barcelona.

Lichtenthaler, U. (2008). Open innovation in practice: An analysis of strategic approaches to technology transactions. IEEE Transactions on Engineering Management, 55, 148-157.

Michelino, F., Caputo, M., Cammarano, A. \& Lamberti, E. (2014). Inbound and outbound open innovation: Organization and performance. Journal of Technology Management \& Innovation, 9(3), 65-82.

Mina, A., Başçavuşoğlu-Moreau, E., \& Hughes, A. (2014). Open service innovation and the firm's search for external knowledge. Research Policy, 43, 853-866.

Pisano G. P., \& Verganti R. (2008). Which kind of collaboration is right for you? Harvard Business Review, December, 1-9.

Schroll, A., \& Mild, A. (2011). Open innovation modes and the role of internal R\&D. European Journal of Innovation Management, 14(4), 475-495.

Seyfettinoğlu, Ü., \& Taşdoğan C. (2014). The relation between firm performance and open innovation: The food and beverages industry case in Turkey. İktisat, Işletme ve Finans, 29, 9-38.

Tidd, J., Bessant, J., \& Pavitt, K. (2005). Managing innovation: Integrating technological, market and organizational change. London: John Wiley \& Sons Ltd.

Van De Vrande, V., De Jong, J. P. J., Vanhaverbeke, W., \& De Rochemont, M. (2009). Open innovation in SMEs: Trends, motives and management challenges. Technovation, 29, 423-437. 


\section{Appendix}

Table A1

Factors Affecting Firm Depth

\begin{tabular}{|c|c|c|c|c|c|c|c|}
\hline \multicolumn{8}{|c|}{ Dependent variable DEP (LS) } \\
\hline $\begin{array}{l}\text { Independent } \\
\text { Variables }\end{array}$ & Turkey & Food & Textile & $\begin{array}{l}\text { Automotive- } \\
\text { Machinery }\end{array}$ & $\begin{array}{l}\text { Mining-Iron- } \\
\text { Steel }\end{array}$ & $\begin{array}{l}\text { Plastic-Met.- } \\
\text { Electronic gd. }\end{array}$ & $\begin{array}{l}\text { Paper-Chem- } \\
\text { Wood }\end{array}$ \\
\hline Constant & $\begin{array}{l}-11.46 \\
(9.70)\end{array}$ & $\begin{array}{c}6.04 \\
(17.73)\end{array}$ & $\begin{array}{c}-5.89 \\
(11.43)\end{array}$ & $\begin{array}{c}1.62 \\
(26.05)\end{array}$ & $\begin{array}{c}26.01 \\
(34.60)\end{array}$ & $\begin{array}{l}-28.63 \\
(19.87)\end{array}$ & $\begin{array}{l}-83.78 \\
(26.27)\end{array}$ \\
\hline $\mathbf{X} 1$ & $\begin{array}{l}0.33 * \\
(0.06)\end{array}$ & $\begin{array}{l}0.54 * \\
(0.12)\end{array}$ & $\begin{array}{l}0.64 * \\
(0.13)\end{array}$ & $\begin{array}{l}1.06^{*} \\
(0.14)\end{array}$ & $\begin{array}{l}0.51 * \\
(0.13)\end{array}$ & - & $\begin{array}{l}0.40^{*} \\
(0.10)\end{array}$ \\
\hline X2_1 & - & - & - & $\begin{array}{c}-0.25 * * * \\
(0.14)\end{array}$ & - & - & - \\
\hline X2_2 & $\begin{array}{l}0.10^{* *} \\
(0.06)\end{array}$ & - & - & - & $\begin{array}{l}0.43 * * \\
(0.17)\end{array}$ & $\begin{array}{c}0.41 * * * \\
(0.24)\end{array}$ & $\begin{array}{l}0.18 * * \\
(0.08)\end{array}$ \\
\hline X2_3 & - & - & - & $\begin{array}{l}-0.59^{*} \\
(0.14)\end{array}$ & - & - & - \\
\hline X3_1 & - & - & - & - & $\begin{array}{l}-0.25 \\
(0.15)\end{array}$ & - & - \\
\hline X3_2 & $\begin{array}{l}-0.15 \\
(0.09)\end{array}$ & - & - & - & $\begin{array}{c}-0.62 * * \\
(0.27)\end{array}$ & $\begin{array}{l}0.33 * * \\
(0.16)\end{array}$ & $\begin{array}{l}-0.54^{*} \\
(0.18)\end{array}$ \\
\hline X4_1 & - & $\begin{array}{c}0.20 * * * \\
(0.10)\end{array}$ & - & - & - & $\begin{array}{l}0.19 * * \\
(0.09)\end{array}$ & $\begin{array}{l}0.59 * \\
(0.15)\end{array}$ \\
\hline X4_2 & - & $\begin{array}{l}-0.45^{*} \\
(0.13)\end{array}$ & $\begin{array}{c}-0.21 * * \\
(0.08)\end{array}$ & - & - & - & - \\
\hline X5 & $\begin{array}{l}0.12 * * \\
(0.05)\end{array}$ & - & - & - & $\begin{array}{l}0.22 \\
(* *)\end{array}$ & - & - \\
\hline X6 & $\begin{array}{l}0.27 * \\
(0.00)\end{array}$ & - & $\begin{array}{c}0.35 * * * \\
(0.19)\end{array}$ & - & - & $\begin{array}{l}0.45^{*} \\
(0.15)\end{array}$ & - \\
\hline X6_1 & - & - & - & - & - & - & $\begin{array}{l}0.38 * \\
(0.12)\end{array}$ \\
\hline X6_2 & - & - & - & - & $\begin{array}{l}0.25 * * \\
(0.13)\end{array}$ & - & - \\
\hline X7_2 & - & - & - & $\begin{array}{c}0.30 \\
(0.18)\end{array}$ & - & - & - \\
\hline X8 & - & $\begin{array}{l}0.25 * * \\
(0.11)\end{array}$ & - & - & - & - & - \\
\hline X9_1 & - & - & $\begin{array}{l}0.18 * * \\
(0.08)\end{array}$ & - & $\begin{array}{l}0.25^{*} \\
(0.08)\end{array}$ & $\begin{array}{l}0.30 * * \\
(0.12)\end{array}$ & - \\
\hline X9_2 & - & - & - & $\begin{array}{c}-0.28 * * \\
(0.14)\end{array}$ & - & $\begin{array}{l}-0.39^{*} \\
(0.13)\end{array}$ & - \\
\hline X10_1 & $\begin{array}{l}0.19 * \\
(0.05)\end{array}$ & $\begin{array}{c}0.27 * * \\
(0.10)\end{array}$ & - & $\begin{array}{l}0.33 * \\
(0.08)\end{array}$ & - & - & -- \\
\hline X10_2 & - & - & - & $\begin{array}{l}0.42 * \\
(0.13)\end{array}$ & - & - & - \\
\hline X11 & $\begin{array}{l}0.38 * \\
(0.06)\end{array}$ & $\begin{array}{c}0.32 * * \\
(0.13)\end{array}$ & - & - & $\begin{array}{c}0.37 * * \\
(0.15)\end{array}$ & $\begin{array}{l}0.52 * \\
(0.18)\end{array}$ & $\begin{array}{c}0.18 * * \\
(0.07)\end{array}$ \\
\hline X12 & $\begin{array}{l}-0.16^{*} \\
(0.05)\end{array}$ & - & - & $\begin{array}{c}-0.37 * * \\
(0.18)\end{array}$ & - & $\begin{array}{c}-0.27 * * * \\
(0.15)\end{array}$ & - \\
\hline X13 & - & - & - & - & $\begin{array}{c}-0.45 * * \\
(0.19)\end{array}$ & - & - \\
\hline
\end{tabular}




\begin{tabular}{|c|c|c|c|c|c|c|c|}
\hline X15 & - & - & - & - & - & $\begin{array}{c}-0.35^{* *} \\
(0.14)\end{array}$ & - \\
\hline X15_1 & $\begin{array}{c}-0.11 * * \\
(0.04)\end{array}$ & - & $\begin{array}{l}1.41^{*} \\
(0.23)\end{array}$ & $\begin{array}{c}-0.22 * * \\
(0.09)\end{array}$ & $\begin{array}{c}-0.31 * * \\
(0.14)\end{array}$ & - & $\begin{array}{c}-0.19 * * \\
(0.08)\end{array}$ \\
\hline X15_2 & - & - & $\begin{array}{l}-0.13 \\
(0.10)\end{array}$ & - & $\begin{array}{l}0.36^{*} \\
(0.13)\end{array}$ & - & - \\
\hline X16_1 & - & - & $\begin{array}{c}0.19 * * * \\
(0.10)\end{array}$ & - & $\begin{array}{l}-0.39 \\
(0.24)\end{array}$ & - & $\begin{array}{l}0.23 * * \\
(0.09)\end{array}$ \\
\hline X16_2 & - & $\begin{array}{c}-0.12 * * * \\
(0.06)\end{array}$ & - & $\begin{array}{c}0.44 * * * \\
(0.25)\end{array}$ & - & - & - \\
\hline X16_3 & - & - & - & - & - & - & $\begin{array}{l}0.58^{*} \\
(0.11)\end{array}$ \\
\hline X17_2 & - & - & - & $\begin{array}{c}-0.37 * * \\
(0.17)\end{array}$ & - & - & - \\
\hline X18 & - & - & - & - & - & $\begin{array}{l}-0.16 \\
(0.11)\end{array}$ & - \\
\hline $\mathbf{R}^{2}$ & 0.58 & 0.79 & 0.82 & 0.79 & 0.69 & 0.59 & 0.69 \\
\hline Adj $R^{2}$ & 0.57 & 0.77 & 0.81 & 0.72 & 0.60 & 0.51 & 0.64 \\
\hline F Test & $61.57 *$ & $46.75^{*}$ & $69.20 *$ & $10.71 *$ & $7.77^{*}$ & $7.18^{*}$ & $14.52 *$ \\
\hline
\end{tabular}

$*, * *, * * *$ At the statistical significance level of $0.01,0.05$ and 0.10 , respectively. Values in parentheses indicate standard errors.

Table A2

Factors Affecting Firm Width

\begin{tabular}{|c|c|c|c|c|c|c|c|}
\hline \multicolumn{8}{|c|}{ Dependent Variable WID (LS) } \\
\hline $\begin{array}{l}\text { Ind e p e nd e n t } \\
\text { Variables }\end{array}$ & Turkey & Food & Textile & $\begin{array}{c}\text { Automotive- } \\
\text { Machinery }\end{array}$ & $\begin{array}{l}\text { Mining- } \\
\text { Iron-Steel }\end{array}$ & $\begin{array}{c}\text { Plastic- } \\
\text { Met.- } \\
\text { Electronic }\end{array}$ & $\begin{array}{c}\text { Paper- } \\
\text { Chem-Wood }\end{array}$ \\
\hline Constant & $\begin{array}{l}-28.43 \\
(10.39)\end{array}$ & $\begin{array}{c}0.86 \\
(11.92) \\
\end{array}$ & $\begin{array}{l}-27.04 \\
(17.50)\end{array}$ & $\begin{array}{l}-69.28 \\
(22.53)\end{array}$ & $\begin{array}{c}39.56 \\
(17.43) \\
\end{array}$ & $\begin{array}{c}2.42 \\
(22.82) \\
\end{array}$ & $\begin{array}{l}-18.23 \\
(14.03)\end{array}$ \\
\hline $\mathbf{X} 1$ & $\begin{array}{l}0.19 * \\
(0.05)\end{array}$ & $\begin{array}{l}0.40 * \\
(0.10) \\
\end{array}$ & $\begin{array}{l}0.42 * \\
(0.09)\end{array}$ & - & - & - & $\begin{array}{l}0.28 * \\
(0.10)\end{array}$ \\
\hline $\mathbf{X} 2$ & - & $\begin{array}{l}-0.24 * \\
(0.07) \\
\end{array}$ & - & - & - & - & - \\
\hline X2_1 & $\begin{array}{l}-0.19 * \\
(0.05) \\
\end{array}$ & - & $\begin{array}{l}-0.19 \\
(0.11) \\
\end{array}$ & - & - & - & - \\
\hline X2_2 & - & - & - & - & - & $\begin{array}{c}0.39 * * \\
(0.19)\end{array}$ & - \\
\hline X2_3 & - & - & - & - & - & - & - \\
\hline X3_1 & - & - & $\begin{array}{l}0.22 * * \\
(0.11) \\
\end{array}$ & - & $\begin{array}{c}-0.34 * * * \\
(0.18)\end{array}$ & - & $\begin{array}{l}0.29 * * \\
(0.12)\end{array}$ \\
\hline X3_2 & - & - & - & - & - & - & - \\
\hline X4_1 & $\begin{array}{l}0.23 * \\
(0.06) \\
\end{array}$ & $\begin{array}{c}0.14 * * * \\
(0.08)\end{array}$ & - & $\begin{array}{c}0.28 \\
(0.18) \\
\end{array}$ & - & $\begin{array}{c}0.19 * * \\
(0.08) \\
\end{array}$ & - \\
\hline X4_2 & - & - & - & - & - & - & - \\
\hline X5 & - & - & - & $\begin{array}{c}0.35 * * \\
(0.13)\end{array}$ & $\begin{array}{c}0.21 * * \\
(0.10)\end{array}$ & $\begin{array}{l}-0.09 \\
(0.10)\end{array}$ & - \\
\hline X6 & $\begin{array}{l}0.26^{*} \\
(0.06)\end{array}$ & $\begin{array}{l}0.36^{*} \\
(0.11)\end{array}$ & - & $\begin{array}{l}0.50^{*} \\
(0.12)\end{array}$ & - & $\begin{array}{l}0.59^{*} \\
(0.10)\end{array}$ & - \\
\hline
\end{tabular}




\begin{tabular}{|c|c|c|c|c|c|c|c|}
\hline X6_1 & - & - & - & - & $\begin{array}{l}0.39 * * \\
(0.16)\end{array}$ & - & - \\
\hline X6_2 & - & - & - & - & - & - & $\begin{array}{c}0.19 * * * \\
(0.10)\end{array}$ \\
\hline $\mathrm{X} 7$ & - & - & - & - & - & - & $\begin{array}{l}-0.28^{*} \\
(0.10)\end{array}$ \\
\hline X7_1 & - & - & - & - & - & $\begin{array}{c}-0.27 * * * \\
(0.15)\end{array}$ & - \\
\hline X7_2 & - & - & - & - & - & - & - \\
\hline $\mathrm{X8}$ & - & $\begin{array}{l}0.30^{* *} \\
(0.12)\end{array}$ & - & $\begin{array}{c}-0.55^{* *} \\
(0.26)\end{array}$ & - & $\begin{array}{c}-0.38 * * \\
(0.14)\end{array}$ & - \\
\hline X9_1 & - & $\begin{array}{c}0.14 \\
(0.10)\end{array}$ & - & - & - & - & $\begin{array}{c}-0.15^{* * *} \\
(0.09)\end{array}$ \\
\hline X9_2 & - & $\begin{array}{l}-0.35^{*} \\
(0.10)\end{array}$ & - & - & - & - & $\begin{array}{c}0.15^{* *} \\
(0.07)\end{array}$ \\
\hline X10_1 & $\begin{array}{l}0.13^{*} \\
(0.05)\end{array}$ & - & - & - & - & - & $\begin{array}{l}0.38^{*} \\
(0.08)\end{array}$ \\
\hline$X 10 \_2$ & $\begin{array}{c}-0.15^{* *} \\
(0.07)\end{array}$ & - & - & - & - & $\begin{array}{c}-0.26 * * * \\
(0.16)\end{array}$ & - \\
\hline X11 & $\begin{array}{l}0.39^{*} \\
(0.06) \\
\end{array}$ & $\begin{array}{l}0.23 * * \\
(0.10)\end{array}$ & $\begin{array}{l}0.42 * \\
(0.13)\end{array}$ & - & $\begin{array}{c}0.45^{* * * *} \\
(0.09)\end{array}$ & ( & $\begin{array}{l}0.21 * * \\
(0.08)\end{array}$ \\
\hline X12 & $\begin{array}{c}-0.10 * * * \\
(0.05) \\
\end{array}$ & - & - & - & - & - & - \\
\hline X13 & - & - & - & - & $\begin{array}{c}-0.32 * * * \\
(0.17) \\
\end{array}$ & $\begin{array}{l}0.46^{* *} \\
(0.22)\end{array}$ & $\begin{array}{c}-0.27 * * * \\
(0.15)\end{array}$ \\
\hline X14 & $\begin{array}{c}0.18 * * * \\
(0.10)\end{array}$ & - & $\begin{array}{l}0.34 * * \\
(0.19)\end{array}$ & - & - & - & - \\
\hline X15 & - & - & - & - & - & - & - \\
\hline X15_1 & - & - & - & - & - & - & - \\
\hline X15_2 & $\begin{array}{c}0.11 * * * \\
(0.10)\end{array}$ & - & - & - & - & - & - \\
\hline X16_1 & - & - & - & $\begin{array}{c}-0.26^{* *} \\
(0.12)\end{array}$ & - & - & - \\
\hline$X 16 \_2$ & - & $\begin{array}{l}-0.28^{*} \\
(0.07)\end{array}$ & $\begin{array}{c}-0.33 * * \\
(0.16)\end{array}$ & - & $\begin{array}{l}-0.33^{*} \\
(0.12)\end{array}$ & - & - \\
\hline X16_3 & - & - & & $\begin{array}{l}0.89^{*} \\
(0.23)\end{array}$ & - & - & - \\
\hline X17 & - & - & $\begin{array}{l}0.20^{*} \\
(0.08)\end{array}$ & & - & - & - \\
\hline X17_1 & - & - & - & $\begin{array}{l}0.30 * * \\
(0.17)\end{array}$ & - & - & - \\
\hline X17_2 & - & - & - & - & - & - & - \\
\hline X18 & - & - & $\begin{array}{c}0.11 \\
(0.08)\end{array}$ & - & - & - & $\begin{array}{l}0.22 * * \\
(0.09)\end{array}$ \\
\hline $\mathbf{R}^{2}$ & 0.50 & 0.74 & 0.71 & 0.59 & 0.41 & 0.54 & 0.63 \\
\hline Adj R ${ }^{2}$ & 0.49 & 0.71 & 0.69 & 0.50 & 0.33 & 0.46 & 0.56 \\
\hline F Test & 41.14 & 26.36 & 27.35 & 7.06 & 5.50 & 7.39 & 9.57 \\
\hline
\end{tabular}

$*, * *, * * *$ : At the statistical significance level of $0.01,0.05$ and 0.10 , respectively.

Values in parentheses indicate standard errors. 


\section{List of Variables}

BRE: Width as a measurement of firm openness

DEP: Depth as a measurement of firm openness

Driving forces for collaboration on innovative activities

X1: The driving forces of your company's collaboration with its stakeholders in innovation activities

Q26 Expanding the competence area of the company

Q27 Access advanced technologies

Q28 To increase internal flexibility within the firm for innovation

Q29 Encouraging the capacity for creativity and ideas development

Q30 Reduce the risks of innovation

Q31 Reduce/share the innovation cost

Internal factors of the company

X2-1, X2-2, X2-3: Strategy 1

Q32 We constantly monitor new market opportunities

Q33 We focus on new products and services

Q34 We want to be a leader in technology

Q35 We focus on bringing innovation through radical changes, rather than step by step

Q36 We try to place the best specialists and scientists on the market in our company

Q37 R\&D and marketing are our core competencies

Q38 We usually use innovative, flexible and extraordinary technologies

X3-1, X3-2, X3-3: Strategy 2

Q39 We have a wide product portfolio at the national level

Q40 We have a broad market portfolio at the national level

Q41 We have a wide product portfolio at the international level

Q42 We have a wide market portfolio at the international level 
Q43 We have a broad technology portfolio

Q44 We focus on market opportunities and innovations in the use of inputs/resources X4-1, X4-2: Protection by intellectual property rights

\section{Q45 Patents}

Q46 Designs

Q47 Trademarks

Q48 Trade secrets

Q49 Confidentiality agreements and other contractual agreements

Q50 Copyright

Q51 Multi-stage production processes

Q52 Delivery time

X5: Organizational and managerial interventions 1

Q53 There is a formal organizational unit within the firm to coordinate and support technological collaboration with stakeholders

Q54 Our company has organizational roles that accelerate cultural change by developing understanding, knowledge, processes and skills necessary for technological collaboration with stakeholders

X6-1, X6-2, X6-3: Organizational and managerial interventions 2

Q55 Senior management in our company is committed to increasing collaboration with stakeholders

Q56 Every collaborative project in our company has an active person to ensure the success of the collaboration

Q57 In our company, the loss-gain relationships between the internal developments and external gains is formally assessed

Q58 Our company is increasingly using the internal research capacity for the screening and evaluation of external information

Q59 Our company uses project management techniques for managing collaborations 
Q60 The outcome and performance of collaboration projects are formally assessed in our company

Q61 Benefits of emerging innovative collaborations are encouraged and rewarded

Q62 Our company uses internet based systems to investigate our potential stakeholders

Q63 Our company uses simulations and virtual prototype tools to promote/provide the development of new products in the collaboration projects

\section{Individual skills}

X7: About your staff working on technological innovations

Q68 There is a high level of collaboration between the functional units to identify and address emerging issues related to innovation activities

Q69 In innovation activities, there is a high interaction between different functional units

\section{Communication skills}

X8-1, X8-2: Staff working on technological innovations

Q64 Our company provides the staff with the necessary time and resources to generate new ideas

Q65 Our staff can easily adapt to new situations

Q66 We place challenging/ambitious and creative goals for our staff

Q67 We are constantly allocating resources to our staff for their professional development

Business environment of the company

X9-1, X9-2, X9-3: Your company’s business environment

Q70 The technology development cost is increasing

Q71 The product life cycles are shortening

Q72 The scale economies resulting from R\&D dropped

Q73 Customer/consumer needs and preferences change very quickly

Q74 Customer/consumer product demand and preferences are highly uncertain 
Q75 It is difficult to predict the change in customer/consumer needs and preferences

Q76 Almost all of the technologies developed in our industry are protected by intellectual property rights and in particular by patents

Factors that reduce collaboration success

X10-1, X10-2: Factors that reduce the success of innovative collaboration with stakeholders

Q85 Stakeholders' technological competencies

Q86 Differences in business culture and management styles among stakeholders

Q87 Reluctance to accept technology/knowledge from outside the company

Q88 Lack of trust among stakeholders

Q89 Lack of mutual interest in collaboration with stakeholders

Q90 Failure of the creation an effective collaboration environment

Types of Open Innovation - Inbound Open Innovation

X11: Factors determining the inbound open innovation activities

Q91 External partners such as customers, competitors, research institutes, consultants, suppliers, governments or universities are directly involved in all our innovation projects

Q92 The success of our all innovation projects depends heavily on the contribution of external partners

Q93 Our company often receives services related to R\&D from external partners

Q94 Our company often purchases intellectual property rights such as patents, copyrights or trademarks for use in innovation projects from external partners

Q95 Our company invests in other companies to obtain a synergy that will be useful in innovation projects

Types of Open Innovation - Outbound Open Innovation

X12: Factors determining the outbound open innovation activities

Q96 Our company frequently sells licenses such as patents, copyrights, or trademarks to other companies to benefit more from innovation activities

Q97 Our company frequently offers royalty agreements to other companies to benefit more from innovation activities 
Q98 Our company supports every possible use of intellectual property rights that we have in order to benefit more from innovation activities

Q99 Our company produces by-products to benefit more from innovation activities Types of Open Innovation- Connected (combined) innovation

X13: Factors that determine the combined open innovation activities

Q100 Our company usually combines the knowledge of all internal and external partners in innovation projects

Q101 Our company coordinates information exchange among partners in innovation projects

Q102 Our company continuously informs internal and external partners about new information in innovation projects

\section{Organizational focus-entrepreneurial orientation}

X14-1, X14-2: Your company's entrepreneurial orientation

Q103 We actively develop/use our capacity to respond effectively to market conditions

Q104 We guarantee the sustainability of our advantages over changes in the industry

Q105 We actively prepare for possible changes in government policies

Organizational focus-Market/Marketplace orientation

X15-1, X15-2: Technological turbulence

Q119 The technology is changing rapidly in the industry we operate in

Q120 Technological changes provide great opportunities in the industry we operate in

Q121 The vast majority of new products/service ideas are possible through technological breakthroughs

Organizational focus-Resource management

X16-1, X16-2: Your company's market/marketplace orientation

Q106 We follow the needs of consumers simultaneously in product design

Q107 We often check the possible effects of changes in our business environment on consumers 
Q108 We notify the whole organization in a short time when there is a major change with the customer or the market

Q109 When we notice a significant improvement in our competitors, any department of ours is slow in communicating this information to other departments

Q110 We tend to react late to changes in our consumers' product or service needs

\section{Technological turbulence}

X17-1, X17-2, X17-3: Your company’s resource orientation

Q111 We strive to ensure that our resources are not easily identified by our competitors

Q112 We continuously strive to ensure that our resources are not easily copied by our competitors

Q113 We spend a lot of time and effort trying to make it difficult for another company to get the same resources

Q114 We strive to make it virtually impossible for another company to use our source composition

Q115 We strive to guarantee that our resources spread to or benefit various departments

Q116 We combine some of our resources to increase our efficiency and effectiveness

Q117 We try to make our resources a trigger in the innovation process

Q118 Our resources are the main force in developing strategies that will enable us to achieve efficiency or effectiveness.

\section{Competition intensity}

X18: Please indicate your opinion about the following sentences regarding the intensity of competition.

Q122 Differentiation of our brand is very difficult because there are many similar services in the market

Q123 This market is very competitive because of the frequent price battles 
Table A3

Provinces and Plates in Turkey

\begin{tabular}{|l|l|}
\hline ADANA & 1 \\
\hline ADIYAMAN & 2 \\
\hline AFYON & 3 \\
\hline AGRI & 4 \\
\hline AMASYA & 5 \\
\hline ANKARA & 6 \\
\hline ANTALYA & 7 \\
\hline ARTVIN & 8 \\
\hline AYDIN & 9 \\
\hline BALIKESIR & 10 \\
\hline BiLECIK & 11 \\
\hline BINGÖL & 12 \\
\hline BiTLIS & 13 \\
\hline BOLU & 14 \\
\hline
\end{tabular}

\begin{tabular}{|c|c|c|c|}
\hline BURDUR & 15 & GÜMÜŞHANE & 29 \\
\hline BURSA & 16 & HAKKARI & 30 \\
\hline ÇANAKKALE & 17 & HATAY & 31 \\
\hline CANKIRI & 18 & ISPARTA & 32 \\
\hline ÇORUM & 19 & İÇEL & 33 \\
\hline DENIZLI & 20 & İTANBUL & 34 \\
\hline DIYAARBAKIR & 21 & İZMIR & 35 \\
\hline EDIRNE & 22 & KARS & 36 \\
\hline ELAZIG̈ & 23 & KASTAMONU & 37 \\
\hline ERZINCAN & 24 & KAYSERI & 38 \\
\hline ERZURUM & 25 & KIRKLARELİ & 39 \\
\hline ESKIŞEHIR & 26 & KIRŞEHIR & 40 \\
\hline GAZIANTEP & 27 & KOCAELI & 41 \\
\hline GIRESUN & 28 & KONYA & 42 \\
\hline
\end{tabular}

\begin{tabular}{|c|c|}
\hline KÜTAHYA & 43 \\
\hline MALATYA & 44 \\
\hline MANISA & 45 \\
\hline K.MARAS & 46 \\
\hline MARDIN & 47 \\
\hline MUĞLA & 48 \\
\hline MUȘ & 49 \\
\hline NEVŞEHIR & 50 \\
\hline NİंGDE & 51 \\
\hline ORDU & 52 \\
\hline RiZE & 53 \\
\hline SAKARYA & 54 \\
\hline SAMSUN & 55 \\
\hline \begin{tabular}{|l} 
SIIRT \\
\end{tabular} & 56 \\
\hline
\end{tabular}

\begin{tabular}{|l|l|}
\hline SINOP & 57 \\
\hline SIVAS & 58 \\
\hline TEKIRDAG & 59 \\
\hline TOKAT & 60 \\
\hline TRABZON & 61 \\
\hline TUNCELI & 62 \\
\hline S.URFA & 63 \\
\hline UŞAK & 64 \\
\hline VAN & 65 \\
\hline YOZGAT & 66 \\
\hline ZONGULDAK & 67 \\
\hline AKSARAY & 68 \\
\hline BAYBURT & 69 \\
\hline KARAMAN & 70 \\
\hline
\end{tabular}

\begin{tabular}{|l|l|}
\hline KIRIKKALE & 71 \\
\hline BATMAN & 72 \\
\hline ŞIRNAK & 73 \\
\hline BARTIN & 74 \\
\hline ARDAHAN & 75 \\
\hline IĞDIR & 76 \\
\hline YALOVA & 77 \\
\hline KARABÜK & 78 \\
\hline KILIS & 79 \\
\hline OSMANIYE & 80 \\
\hline DÜZCE & 81 \\
\hline
\end{tabular}

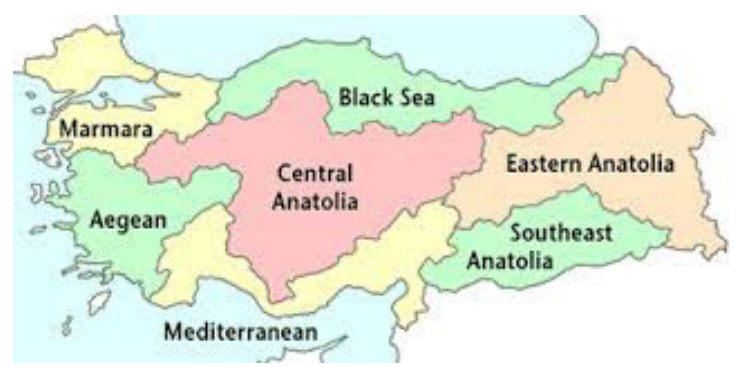

Map A1. Geographical Regions in Turkey

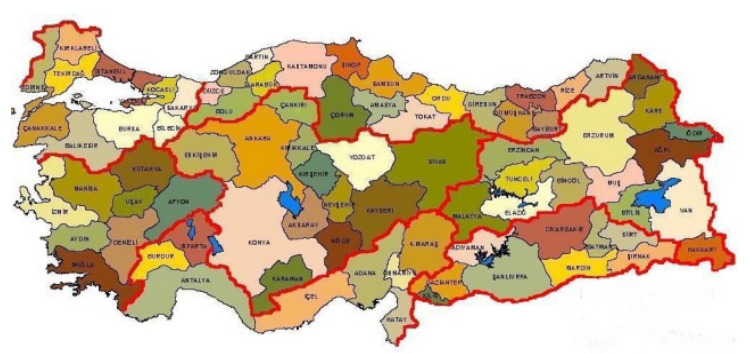

Map A2. Provinces in Turkey according to Regions 